Published in final edited form as:

Cochrane Database Syst Rev. ; 3: CD004233. doi:10.1002/14651858.CD004233.pub3.

\title{
Single dose oral celecoxib for acute postoperative pain in adults
}

\author{
Sheena Derry ${ }^{1}$ and $\mathbf{R}$ Andrew Moore ${ }^{1}$ \\ ${ }^{1}$ Pain Research and Nuffield Department of Clinical Neurosciences (Nuffield Division of \\ Anaesthetics), University of Oxford, Oxford, UK
}

\begin{abstract}
Background-This is an update of a review published in The Cochrane Library 2008, Issue 4. Celecoxib is a selective cyclo-oxygenase-2 (COX-2) inhibitor usually prescribed for the relief of chronic pain in osteoarthritis and rheumatoid arthritis. Celecoxib is believed to be associated with fewer upper gastrointestinal adverse effects than conventional non-steroidal anti-inflammatory drugs (NSAIDs). Its effectiveness in acute pain was demonstrated in the earlier reviews.
\end{abstract}

Objectives-To assess analgesic efficacy and adverse effects of a single oral dose of celecoxib for moderate to severe postoperative pain.

Search methods-We searched the Cochrane Central Register of Controlled Trials (CENTRAL), MEDLINE, EMBASE, the Oxford Pain Database, and ClinicalTrials.gov. The most recent search was to 3 January 2012.

Selection criteria-We included randomised, double-blind, placebo-controlled trials (RCTs) of adults prescribed any dose of oral celecoxib or placebo for acute postoperative pain.

Data collection and analysis-Two review authors assessed studies for quality and extracted data. We converted summed pain relief (TOTPAR) or pain intensity difference (SPID) into dichotomous information, yielding the number of participants with at least $50 \%$ pain relief over four to six hours, and used this to calculate the relative benefit (RB) and number needed to treat to benefit (NNT) for one patient to achieve at least $50 \%$ of maximum pain relief with celecoxib who would not have done so with placebo. We used information on use of rescue medication to calculate the proportion of participants requiring rescue medication and the weighted mean of the median time to use.

Copyright @ 2012 The Cochrane Collaboration. Published by John Wiley \& Sons, Ltd

Contact address: Sheena Derry, Pain Research and Nuffield Department of Clinical Neurosciences (Nuffield Division of Anaesthetics), University of Oxford, Churchill Hospital, Oxford, Oxfordshire, OX3 7LE, UK. sheena.derry@ pru.ox.ac.uk. Editorial group: Cochrane Pain, Palliative and Supportive Care Group.

Publication status and date: New search for studies and content updated (no change to conclusions), published in Issue 3, 2012. Review content assessed as up-to-date: 3 January 2012.

CONTRIBUTIONS OF AUTHORS: JB, JR, and RAM undertook searches, extracted and analysed the data. SD and RAM carried out searches, data extraction, analysis, and writing for both updates.

DECLARATIONS OF INTEREST: SD has no interests to declare. RAM has consulted for various pharmaceutical companies and received lecture fees from pharmaceutical companies related to analgesics and other healthcare interventions. Both authors have received research support from charities, government, and industry sources at various times: no such support was received for this work. 
Main results-Eight studies (1380 participants) met the inclusion criteria. We identified five potentially relevant unpublished studies in the most recent searches, but data were not available at this time. The number of included studies therefore remains unchanged.

The NNT for celecoxib $200 \mathrm{mg}$ and $400 \mathrm{mg}$ compared with placebo for at least $50 \%$ of maximum pain relief over four to six hours was 4.2 (95\% confidence interval (CI) 3.4 to 5.6) and 2.5 (2.2 to 2.9) respectively. The median time to use of rescue medication was 6.6 hours with celecoxib 200 $\mathrm{mg}, 8.4$ with celecoxib $400 \mathrm{mg}$, and 2.3 hours with placebo. The proportion of participants requiring rescue medication over 24 hours was $74 \%$ with celecoxib $200 \mathrm{mg}$, 63\% for celecoxib $400 \mathrm{mg}$, and $91 \%$ for placebo. The NNT to prevent one patient using rescue medication was 4.8 (3.5 to 7.7) and 3.5 (2.9 to 4.6) for celecoxib $200 \mathrm{mg}$ and $400 \mathrm{mg}$ respectively. Adverse events were generally mild to moderate in severity, and were experienced by a similar proportion of participants in celecoxib and placebo groups. One serious adverse event probably related to celecoxib was reported.

Authors' conclusions-Single-dose oral celecoxib is an effective analgesic for postoperative pain relief. Indirect comparison suggests that the $400 \mathrm{mg}$ dose has similar efficacy to ibuprofen $400 \mathrm{mg}$.

\section{Medical Subject Headings (MeSH)}

Acute Pain [*drug therapy]; Administration, Oral; Cyclooxygenase 2 Inhibitors [*administration $\&$ dosage]; Pain, Postoperative [*drug therapy]; Pyrazoles [*administration \& dosage]; Randomized Controlled Trials as Topic; Sulfonamides [*administration \& dosage]

\section{MeSH check words}

Humans

\section{BACKGROUND}

This is an update of a review published in The Cochrane Library in Issue 4, 2008, which in turn updated the review in Issue 1, 2003.

\section{Description of the condition}

Acute pain occurs as a result of tissue damage either accidentally due to an injury or as a result of surgery. Acute postoperative pain is a manifestation of inflammation due to tissue injury. The management of postoperative pain and inflammation is a critical component of patient care.

This is one of a series of reviews whose aim is to present evidence for relative analgesic efficacy through indirect comparisons with placebo, in very similar trials performed in a standard manner, with very similar outcomes, and over the same duration. Such relative analgesic efficacy does not in itself determine choice of drug for any situation or patient, but guides policy-making at the local level. The series includes well-established analgesics such as paracetamol (Toms 2008), naproxen (Derry C 2009a), diclofenac (Derry P 2009), and ibuprofen (Derry C 2009b), and newer cyclo-oxygenase-2 selective analgesics, such as 
lumiracoxib (Roy 2010) and etoricoxib (Clarke 2012). An overview brings together the results from all the individual drug reviews (Moore 2011a).

\section{Acute pain trials}

Single-dose trials in acute pain are commonly short in duration, rarely lasting longer than 12 hours. The numbers of participants are small, allowing no reliable conclusions to be drawn about safety.

To show that the analgesic is working it is necessary to use placebo (McQuay 2005). There are clear ethical considerations in doing this. These ethical considerations are answered by using acute pain situations where the pain is expected to go away, and by providing additional analgesia, commonly called rescue analgesia, if the pain has not diminished after about an hour. This is reasonable, because not all participants given an analgesic will have significant pain relief. Approximately $18 \%$ of participants given placebo will have significant pain relief (Moore 2006), and up to 50\% may have inadequate analgesia with active medicines. The use of additional or rescue analgesia is hence important for all participants in the trials.

Clinical trials measuring the efficacy of analgesics in acute pain have been standardised over many years. Trials have to be randomised and double-blind. Typically, in the first few hours or days after an operation, patients develop pain that is moderate to severe in intensity, and will then be given the test analgesic or placebo. Pain is measured using standard pain intensity scales immediately before the intervention, and then using pain intensity and pain relief scales over the following four to six hours for shorter-acting drugs, and up to 12 or 24 hours for longer-acting drugs. Pain relief of half the maximum possible pain relief or better (at least $50 \%$ pain relief) is typically regarded as a clinically useful outcome. For patients given rescue medication it is usual for no additional pain measurements to be made, and for all subsequent measures to be recorded as initial pain intensity or baseline (zero) pain relief (baseline observation carried forward). This process ensures that analgesia from the rescue medication is not wrongly ascribed to the test intervention. In some trials the last observation is carried forward, which gives an inflated response for the test intervention compared to placebo, but the effect has been shown to be negligible over four to six hours (Moore 2005a). Patients usually remain in the hospital or clinic for at least the first six hours following the intervention, with measurements supervised, although they may then be allowed home to make their own measurements in trials of longer duration.

Knowing the relative efficacy of different analgesic drugs at various doses can be helpful. Results from completed reviews of many different analgesics have been brought together to facilitate (indirect) comparisons in a recently published acute pain overview (Moore 2011a), and analgesics relevant to dentistry are discussed in Barden 2004 and Derry 2011.

\section{Description of the intervention}

Selective cyclo-oxygenase-2 inhibitors or 'coxibs' were developed to address the problem of upper gastrointestinal bleeding associated with traditional non-steroidal anti-inflammatory drugs (NSAIDs) (Hawkey 2001). Celecoxib (brand names Celebrex, Celebra, Onsenal) was one of the first of the new generation of NSAIDs known as selective cyclo-oxygenase-2 
inhibitors (COX-2 inhibitors) or 'coxibs', and Celebrex ${ }^{\circledR}$ is currently licensed for the relief of osteoarthritis and rheumatoid arthritis pain in many countries around the world, including the United Kingdom and United States of America. The drug is licensed for acute pain in the United States and some other regulatory areas, but not in the United Kingdom. It is available by prescription only in many countries, as $50 \mathrm{mg}, 100 \mathrm{mg}, 200 \mathrm{mg}$, or $400 \mathrm{mg}$ capsules, but generic formulations are available in some parts of Asia and the Far East, where patents have expired. It is most often used for chronic painful conditions, such as osteoarthritis, where the usual adult dose is $100 \mathrm{mg}$ to $200 \mathrm{mg}$ twice daily. In acute painful conditions, such as postoperative pain and menstrual pain, up to $400 \mathrm{mg}$ is sometimes given as a single, or starting dose. In primary care in England in 2010, there were 460,000 prescriptions for celecoxib, with almost equal numbers for the $100 \mathrm{mg}$ and $200 \mathrm{mg}$ doses (PACT 2010).

\section{How the intervention might work}

NSAIDs have pain-relieving, antipyretic, and anti-inflammatory properties, and are thought to relieve pain by inhibiting cyclo-oxygenases and thus the production of prostaglandins (Hawkey 1999). Prostaglandins occur throughout body tissues and fluids and act to stimulate pain nerve endings and promote/inhibit the aggregation of blood platelets. Cyclo-oxygenase has at least two isoforms: $\mathrm{COX}-1$ and $\mathrm{COX}-2$. COX-1 is constitutive while COX-2 is induced at sites of inflammation and produces the prostaglandins involved in inflammatory responses and pain mediation (Grahame-Smith 2002). Unlike traditional NSAIDs such as ibuprofen and ketoprofen, the coxibs are selective inhibitors, blocking primarily the action of COX-2, providing pain relief and causing fewer gastrointestinal effects (Moore 2005b). In addition, they should not precipitate bleeding events through inhibition of platelet aggregation (Straube 2005).

In common with other NSAIDs, COX-2 inhibitors can give rise to fluid retention and renal damage (Garner 2002), so particular caution is needed in the elderly (Hawkey 2001). COX-2 inhibitors have been implicated in increased cardiovascular problems in long-term use, but this is complicated by differences in pharmacology and pharmacokinetics (Patrono 2009). Moreover, recent evidence indicates that prior cardiac damage may be a more important trigger than any particular drug or class of drug (Ruff 2011).

\section{OBJECTIVES}

To evaluate the analgesic efficacy and safety of celecoxib in the treatment of acute postoperative pain, using methods that permit comparison with other analgesics evaluated in the same way, using wider criteria of efficacy recommended by an in-depth study at the individual patient level (Moore 2005a; Moore 2011b).

\section{METHODS}

\section{Criteria for considering studies for this review}

Types of studies-We included studies if they were full publications of double-blind trials of a single-dose oral celecoxib against placebo for the treatment of moderate to severe postoperative pain in adults, with at least 10 participants randomly allocated to each treatment group. We included multiple-dose studies if appropriate data from the first dose 
were available, and included cross-over studies provided that data from the first arm were presented separately.

We excluded studies if they were:

- posters or abstracts not followed up by full publication;

- $\quad$ reports of trials concerned with pain other than postoperative pain (including experimental pain);

- trials using healthy volunteers;

- trials where pain relief was assessed by clinicians, nurses or carers (i.e. not patientreported);

- trials of less than four hours' duration or which failed to present data over four to six hours postdose.

Types of participants-We included studies of adult participants (15 years old or above) with established moderate to severe postoperative pain. For studies using a visual analogue scale (VAS), pain of at least moderate intensity was assumed when the VAS score was greater than $30 \mathrm{~mm}$ (Collins 1997). We included trials of patients with postpartum pain provided the pain investigated resulted from episiotomy or Caesarean section (with or without uterine cramp). We excluded trials investigating pain due to uterine cramps alone.

Types of interventions-Orally administered celecoxib or matched placebo for relief of postoperative pain.

Types of outcome measures-Data collected included the following if available:

- $\quad$ patient characteristics;

- $\quad$ pain model;

- patient-reported pain at baseline (physician, nurse, or carer reported pain would not be included in the analysis);

- $\quad$ patient-reported pain relief expressed hourly over four to six hours using validated scales, or reported total pain relief (TOTPAR) at four to six hours;

- patient-reported pain intensity expressed hourly over four to six hours using validated pain scales, or reported summed pain intensity difference (SPID) at four to six hours;

- patient-reported global evaluation of treatment using validated scale;

- number of participants using rescue medication, and the time of assessment;

- time to use of rescue medication;

- withdrawals - all-cause, adverse event;

- adverse events - participants experiencing one or more, and any serious adverse event, and the time of assessment. 
Primary outcomes: Participants achieving at least 50\% pain relief over four to six hours.

\section{Secondary outcomes}

1. Median (or mean) time to use of rescue medication.

2. Participants using rescue medication.

3. Participants with:

i. any adverse event;

ii. any serious adverse event (as reported in the study);

iii. withdrawal due to an adverse event.

4. Other withdrawals.

\section{Search methods for identification of studies}

We applied no language restriction.

Electronic searches-We searched the following electronic databases:

- the Cochrane Central Register of Controlled Trials (CENTRAL) (The Cochrane Library 2011, Issue 12);

- MEDLINE via Ovid (1966 to 3 January 2012);

- $\quad$ EMBASE via Ovid (1980 to 3 January 2012);

- Oxford Pain Database (Jadad 1996a);

- ClinicalTrials.gov (on 3 January 2012) for update only.

See Appendix 1 for the MEDLINE search strategy, Appendix 2 for the EMBASE search strategy, and Appendix 3 for the Cochrane CENTRAL search strategy.

Searches for the original review were up to May 2002, and for the first update were to July 2008.

Searching other resources-We manually searched reference lists of retrieved studies. We did not search abstracts, conference proceedings, and other grey literature. We did not contact manufacturers. For this update we searched ClinicalTrials.gov for any unpublished and ongoing studies, and attempted to contact the study sponsors for further information.

\section{Data collection and analysis}

Selection of studies-Two review authors independently assessed and agreed the search results for studies that might be included in the review. We resolved disagreements by consensus or referral to a third review author.

Data extraction and management-Two review authors independently extracted data and recorded on a standard Data Extraction form. One author entered data suitable for pooling into RevMan 5.1 (RevMan 2011). 
Assessment of risk of bias in included studies-Two review authors independently assessed each study using a three-item, five-point scale (Jadad 1996b), and agreed a consensus score.

The scale used is as follows.

- Is the study randomised? If yes - one point.

- Is the randomisation procedure reported and is it appropriate? If yes add one point, if no deduct one point.

- Is the study double-blind? If yes then add one point.

- Is the double-blind method reported and is it appropriate? If yes add one point, if no deduct one point.

- Are the reasons for patient withdrawals and dropouts described? If yes add one point.

We also completed a 'Risk of bias' table, considering randomisation, allocation concealment, blinding, incomplete outcome data, and size.

Measures of treatment effect-We used relative risk (or 'risk ratio', RR) to establish statistical difference. We used numbers needed to treat (NNT) and pooled percentages as absolute measures of benefit or harm.

We use the following terms to describe adverse outcomes in terms of harm or prevention of harm:

- When significantly fewer adverse outcomes occur with diclofenac than with control (placebo or active) we use the term the number needed to treat to prevent one event (NNTp).

- When significantly more adverse outcomes occur with diclofenac compared with control (placebo or active) we use the term the number needed to harm or cause one event (NNH).

Unit of analysis issues-We accepted only randomisation to the individual patient.

Dealing with missing data-The only likely issue with missing data in these studies is from imputation using last observation carried forward when a patient requests rescue medication. We have previously shown that this does not affect results for up to six hours after taking study medication (Barden 2004).

Assessment of heterogeneity-We examined heterogeneity visually using L'Abbé plots (L'Abbé 1987).

Data synthesis-We followed QUOROM guidelines (Moher 1999). For efficacy analyses we used the number of participants in each treatment group who were randomised, received medication, and provided at least one post baseline assessment. For safety analyses we used number of participants randomised to each treatment group who took the study medication. 
We planned analyses for different doses. For each study we converted the mean TOTPAR, SPID, VAS TOTPAR, or VAS SPID (Appendix 4) values for active and placebo to $\%$ maxTOTPAR or \%maxSPID by division into the calculated maximum value (Cooper 1991), and calculated the proportion of participants in each treatment group who achieved at least 50\% maxTOTPAR using verified equations (Moore 1996; Moore 1997a; Moore 1997b). We then converted these proportions into the number of participants achieving at least $50 \%$ max-TOTPAR by multiplying by the total number of participants in the treatment group. We used this information on the number of participants with at least 50\% maxTOTPAR for active and placebo to calculate relative benefit or relative risk, and number needed to treat to benefit (NNT).

We accepted the following pain measures for the calculation of TOTPAR or SPID:

- five-point categorical pain relief (PR) scales with comparable wording to 'none, slight, moderate, good or complete';

- four-point categorical pain intensity (PI) scales with comparable wording to 'none, mild, moderate, severe';

- VAS for pain relief;

- VAS for pain intensity.

If none of these measures were available, we used the number of participants reporting 'very good or excellent' on a five-point categorical global scale with the wording 'poor, fair, good, very good, excellent' for the number of participants achieving at least 50\% pain relief (Collins 2001).

For each treatment group we extracted the number of participants reporting treatmentemergent adverse effects, and calculated relative benefit and risk estimates with $95 \%$ confidence intervals (CI) using a fixed-effect model (Morris 1995). We calculated NNT and number needed to treat to harm (NNH) and 95\% CI using the pooled number of events using the method devised by Cook and Sackett (Cook 1995). We assumed a statistically significant difference from control when the $95 \% \mathrm{CI}$ of the relative risk or relative benefit did not include one.

Subgroup analysis and investigation of heterogeneity-We planned subgroup analyses to determine the effect of dose and presenting condition (pain model), and sensitivity analyses for high versus low (two or fewer versus three or more) quality trials. A minimum of two trials and 200 participants had to be available in any subgroup or sensitivity analysis (Moore 1998), which was restricted to the primary outcome (50\% pain relief over four to six hours). We determined significant differences between NNT, NNTp, or NNH for different groups in subgroup and sensitivity analyses using the $\mathrm{z}$ test (Tramèr 1997).

Sensitivity analysis-We planned sensitivity analyses for pain model (dental versus other postoperative pain), trial size (39 or fewer versus 40 or more per treatment arm), and quality score (2 versus 3 or more). 


\section{RESULTS \\ Description of studies}

See: Characteristics of included studies; Characteristics of excluded studies; Characteristics of studies awaiting classification.

Updated searches did not find any published new studies for inclusion. However, we did identify five potentially relevant unpublished studies that are completed.

- Two in which celecoxib was used as an active comparator for indomethacin (IND2-08-03) and diclofenac (DIC2-08-03). Both were placebo-controlled. Although these studies are completed, the research programme is still under development and the data remain confidential. The study sponsor (Iroko) has said they will provide notice when they are published.

- Two in which celecoxib was used as an active comparator for an experimental compound, ARRY-371797. One (ARRY-797-222) is placebo-controlled, but the other (ARRY-797-221) may not be. We have requested further details from the study sponsor (Array BioPharma).

- One in which celecoxib is compared with etodolac and placebo (177-CL-102). We have been unable to contact the study sponsor.

Eight studies fulfilled the inclusion criteria and were available (Malmstrom 1999; Gimbel 2001; Doyle 2002; Malmstrom 2002; Kellstein 2004; Cheung 2007; Moberly 2007; Fricke 2008). Two studies (Malmstrom 1999; Gimbel 2001) were in the first review. We excluded two studies after reading the full paper (Salo 2003; White 2007). One study (Shirota 2001) is in Chinese and has not been translated. Details of included and excluded studies, and studies awaiting classification, are in the corresponding 'Characteristics of studies' tables (Characteristics of included studies; Characteristics of excluded studies; Characteristics of studies awaiting classification).

Celecoxib $200 \mathrm{mg}$ was used in five treatment arms (Malmstrom 1999; Gimbel 2001; Doyle 2002; Malmstrom 2002; Kellstein 2004), and celecoxib $400 \mathrm{mg}$ in four treatment arms (Malmstrom 2002; Cheung 2007; Moberly 2007; Fricke 2008). In total 1380 participants were analysed; 497 received celecoxib $200 \mathrm{mg}$, 415 received celecoxib $400 \mathrm{mg}$, and 468 received placebo.

Seven studies (Malmstrom 1999; Doyle 2002; Malmstrom 2002; Kellstein 2004; Moberly 2007; Cheung 2007; Fricke 2008) enrolled participants with dental pain following extraction of at least one impacted third molar, and one (Gimbel 2001) enrolled participants with pain following uncomplicated orthopaedic surgery. Trial duration was eight hours in two trials, 12 hours in three trials, and 24 hours in three trials. Three trials (Malmstrom 1999; Gimbel 2001; Doyle 2002) were multiple-dose studies, but provided data on the first dose for at least some outcomes. 


\section{Risk of bias in included studies}

Five studies were given a quality score of five (Malmstrom 1999; Doyle 2002; Malmstrom 2002; Cheung 2007; Fricke 2008), two a score of four (Kellstein 2004; Moberly 2007), and one study a score of three (Gimbel 2001). Details are in the 'Characteristics of included studies' table.

We completed a 'Risk of bias' table and results are presented graphically in Figure 1, and summarised in Figure 2. The major threat to reliability was the relatively small size of the studies.

\section{Effects of interventions}

Eight studies met the inclusion criteria and provided data for analysis. Details of results in individual studies are in Appendix 5 (efficacy) and Appendix 6 (adverse events and withdrawals).

\section{Number of participants achieving at least $50 \%$ pain relief Celecoxib $200 \mathrm{mg}$ versus placebo}

- Four studies provided data (Malmstrom 1999; Gimbel 2001; Malmstrom 2002; Kellstein 2004); 423 participants were treated with celecoxib $200 \mathrm{mg}$ and 282 with placebo.

- The proportion of participants experiencing at least 50\% pain relief over four to six hours with celecoxib $200 \mathrm{mg}$ was 35\% (149/423).

- The proportion of participants experiencing at least $50 \%$ pain relief over four to six hours with placebo was $11 \%(32 / 282)$.

- The relative benefit of treatment compared with placebo was 3.5 (2.4 to 5.1); the number needed to treat to benefit (NNT) was 4.2 (3.4 to 5.6) (Analysis 1.1; Figure 3; Appendix 7).

For every four participants treated with celecoxib $200 \mathrm{mg}$, one would experience at least $50 \%$ pain relief who would not have done so with placebo.

\section{Celecoxib $400 \mathrm{mg}$ versus placebo}

- Four studies provided data (Malmstrom 2002; Moberly 2007; Cheung 2007; Fricke 2008); 415 participants were treated with celecoxib $400 \mathrm{mg}$ and 205 with placebo.

- The proportion of participants experiencing at least 50\% pain relief over four to six hours with celecoxib $400 \mathrm{mg}$ was $44 \%$ (184/415).

- The proportion of participants experiencing at least $50 \%$ pain relief over four to six hours with placebo was $4 \%(9 / 205)$.

- The relative benefit of treatment compared with placebo was 11.5 (5.9 to 22); the NNT was 2.5 (2.2 to 2.9) (Analysis 2.1; Figure 4; Appendix 7).

For every five participants treated with celecoxib $400 \mathrm{mg}$, two would experience at least $50 \%$ pain relief who would not have done so with placebo. 
There was a significant difference between celecoxib $200 \mathrm{mg}$ and celecoxib $400 \mathrm{mg}(\mathrm{z}=$ $3.92, \mathrm{P}<0.0001)$.

\begin{tabular}{llllllll}
\hline Summary of results: 50\% pain relief over $\mathbf{4}$ to $\mathbf{6}$ hours & & & & \\
\hline Dose (mg) & Pain model & Studies & Participants & Celecoxib \% & Placebo \% & $\begin{array}{l}\text { Relative } \\
\text { benefit } \\
\text { (RB) } \\
\text { (95\% } \\
\text { CI) }\end{array}$ & NNT (95\% CI) 50\% \\
\hline $200 \mathrm{mg}$ & Dental + Orthopaedic & 4 & 705 & 35 & 11 & $\begin{array}{l}3.5(2.4 \\
\text { to 5.0) }\end{array}$ & $4.2(3.4$ to 5.6) \\
\hline $200 \mathrm{mg}$ & Dental & 3 & 423 & 33 & 1 & $\begin{array}{l}16(5.1 \\
\text { to 49) }\end{array}$ & $3.2(2.7$ to 3.9) \\
\hline $400 \mathrm{mg}$ & Dental & 4 & 620 & 34 & 4 & $\begin{array}{l}11(5.9 \\
\text { to 22) }\end{array}$ & $2.5(2.2$ to 2.9) \\
\hline
\end{tabular}

\section{Use of rescue medication}

Number of participants using rescue medication over 24 hours: All studies reported some information on use of rescue medication. The time at which use of rescue medication was censored varied between studies. The weighted mean proportion of participants requiring rescue medication by 24 hours was $74 \%$ for celecoxib $200 \mathrm{mg}$ (133/181), 63\% for celecoxib $400 \mathrm{mg}$ (228/364), and 91\% for placebo (181/199 participants). Significantly fewer participants used rescue medication with celecoxib than placebo $(200 \mathrm{mg}$ : relative risk (RR) 0.8 (0.7 to 0.9), NNT to prevent use of rescue medication 4.8 (3.5 to 7.7)); $400 \mathrm{mg}$ : RB 0.7 (0.6 to 0.8 ), NNT to prevent use of rescue medication 3.5 (2.9 to 4.6$)$ ). The difference between the two doses of celecoxib was not significant $(\mathrm{z}=1.37, \mathrm{P}=0.085)$.

The proportion of participants requiring rescue medication was also reported at eight hours (Gimbel 2001, 44\%) and 12 hours (Doyle 2002, 41\%) for celecoxib $200 \mathrm{mg}$, and at six hours (Moberly 2007, 24\%) for celecoxib $400 \mathrm{mg}$.

\begin{tabular}{llllllll}
\hline \multicolumn{7}{l}{ Summary of results: use of rescue medication within 24 hours } \\
\hline Dose (mg) & Pain model & Studies & Participants & Celecoxib \% & Placebo \% & RB (95\% CI) & NNTp (95\% CI) \\
\hline $200 \mathrm{mg}$ & Dental & 2 & 271 & 73.5 & 94.4 & $\begin{array}{l}0.78(0.70 \text { to } \\
0.86)\end{array}$ & 4.8 (3.5 to 7.8$)$ \\
\hline $400 \mathrm{mg}$ & Dental & 3 & 518 & 62.6 & 90.9 & $\begin{array}{l}0.68(0.62 \text { to } \\
0.74)\end{array}$ & $3.5(2.9$ to 4.6$)$ \\
\hline
\end{tabular}

Time to use of rescue medication: The median time to use of rescue medication was highly variable, particularly for the celecoxib treatment arms. It ranged from two to $>12$ hours for celecoxib $200 \mathrm{mg}, 3.8$ to $>12$ hours for celecoxib $400 \mathrm{mg}$, and 1.3 to 3.9 hours for placebo. The weighted mean of the median time to use of rescue medication was 6.6 hours for celecoxib $200 \mathrm{mg}, 8.4$ hours for celecoxib $400 \mathrm{mg}$, and 2.3 hours for placebo (2.6 in $200 \mathrm{mg}$ trials and 1.6 in $400 \mathrm{mg}$ trials). For dental studies only the weighted mean of the median 
time to use of rescue medication was 6.1 hours for celecoxib $200 \mathrm{mg}$, and 1.6 hours for placebo.

\begin{tabular}{llllll}
\hline \multicolumn{6}{l}{ Summary of results: weighted mean of median time to use of rescue medication } \\
\hline Dose (mg) & Pain model & Studies & Participants & Celecoxib (hr) & Placebo (hr) \\
\hline $200 \mathrm{mg}$ & Dental + Orthopaedic & 5 & 805 & 6.6 & 2.6 \\
\hline $200 \mathrm{mg}$ & Dental & 4 & 523 & 6.1 & 1.5 \\
\hline $400 \mathrm{mg}$ & Dental & 4 & 620 & 8.4 & 1.6 \\
\hline
\end{tabular}

Adverse events-All studies except (Malmstrom 1999) reported the number of participants with one or more adverse event for each treatment arm, although the time over which the information was collected varied between trials, from eight to 24 hours (Appendix 6). It was unclear in some reports whether the adverse event reports covered only the duration of the trial, or whether they included any adverse events occurring between the end of the trial and a follow-up visit some days later. Only one study arm reported a significant difference between placebo and celecoxib (400 mg) (Malmstrom 2002). There was no significant difference between celecoxib $400 \mathrm{mg}$ and placebo when studies were pooled (Analysis 2.3), or for individual or pooled studies for celecoxib $200 \mathrm{mg}$ (Analysis 1.3), so we did not calculate numbers needed to treat to harm (NNHs). Adverse events were generally described as mild to moderate in severity.

\begin{tabular}{llllllll}
\hline \multicolumn{2}{l}{ Summary of results: participants with at least one adverse event } \\
\hline Dose (mg) & Pain model & Studies & Participants & Celecoxib \% & Placebo \% & RR (95\% CI) & NNH (95\% CI) \\
\hline $200 \mathrm{mg}$ & Dental + Orthopaedic & 4 & 669 & 16 & 17 & $\begin{array}{l}0.90(0.63 \text { to } \\
1.3)\end{array}$ & Not calculated \\
\hline $200 \mathrm{mg}$ & Dental & 3 & 382 & 20 & 18 & $\begin{array}{l}0.97(0.63 \text { to } \\
1.5)\end{array}$ & Not calculated \\
\hline $400 \mathrm{mg}$ & Dental & 4 & 521 & 34 & 42 & $\begin{array}{l}1.05(0.85 \text { to } \\
1.3)\end{array}$ & Not calculated \\
\hline
\end{tabular}

Two studies reported serious adverse events. Malmstrom 2002 reported one serious adverse event in each of the $200 \mathrm{mg}$ and $400 \mathrm{mg}$ treatment arms. These events were reported at the post study visit and were judged unrelated to the study medication. Cheung 2007 reported one serious adverse event in a participant treated with celecoxib $400 \mathrm{mg}$. The event, rhabdomyolysis, occurred two days after the study, and was judged to be probably related to the study medication by the trialists, although the patient had received a number of other medications both pre and post study. No statistical analysis of serious adverse events was possible.

One adverse event withdrawal was reported for celecoxib $200 \mathrm{mg}$ (Malmstrom 1999) and for celecoxib $400 \mathrm{mg}$ (Cheung 2007), and four for placebo (Malmstrom 1999; Cheung 2007). 
Other withdrawals-Withdrawals for reasons other than lack of efficacy (participants who use rescue medication) were uncommon and usually due to protocol violations (Appendix 6). No further statistical analysis of withdrawals was possible.

\section{Sensitivity analyses}

Pain model: One trial using celecoxib $200 \mathrm{mg}$ (Gimbel 2001) included participants who had undergone orthopaedic surgery. Excluding this trial from the primary analysis left dental trials only, giving a relative benefit for treatment compared with placebo of 16 (5.1 to 49), and a NNT for at least 50\% pain relief over four to six hours of 3.2 (2.7 to 3.9). This apparently better efficacy in dental trials is due to the fact that the event rate in the placebo group of the orthopaedic trial was much higher (21\%) than in the placebo groups of the dental trials ( $1 \%$ to $4 \%$ ), while the event rate in the celecoxib group of the orthopaedic trial was more similar (39\%) to the dental trials (23\% to $43 \%$ ). It is not possible to draw any firm conclusions about the effect of pain model with only one non-dental trial in this data set.

Quality score: All studies scored three or more for quality, so we carried out no sensitivity analysis.

Trial size: All studies enrolled more than 40 participants per treatment arm, so we carried out no sensitivity analysis.

\section{DISCUSSION}

\section{Summary of main results}

No new data were available for this updated review. The review in 2008 included 497 participants treated with a single dose of celecoxib $200 \mathrm{mg}$, more than twice the number as in the first review, giving a more robust (Moore 1998), but almost identical result. It also included 415 participants treated with a single dose of $400 \mathrm{mg}$ celecoxib (NLM 2002). The number needed to treat to benefit (NNT) for 50\% pain relief over four to six hours was significantly better for $400 \mathrm{mg}$ (NNT 2.5, 2.2 to 2.9) than for $200 \mathrm{mg}$ (NNT 4.2, 3.4 to 5.6) $(\mathrm{P}<0.0001)$.

The same methods and analyses have been conducted, therefore it is possible to compare the NNT for a single dose of oral celecoxib with that of a single dose of other nonsteroidal antiinflammatory drugs (NSAIDs). Analgesics with comparable efficacy to celecoxib $200 \mathrm{mg}$ include aspirin 600/650 mg (NNT 4.2 (3.8 to 4.6); Derry 2012), and paracetamol $1000 \mathrm{mg}$ (NNT 3.6 (3.2 to 4.1) (Toms 2008). Analgesics with comparable efficacy to celecoxib 400 $\mathrm{mg}$ include naproxen 500/550 mg (NNT 2.7 (2.3 to 3.3), (Derry C 2009a), and ibuprofen $400 \mathrm{mg}$ (NNT 2.5 (2.4 to 2.6) (Derry C 2009b). An overview of analgesic efficacy in acute pain summarises all available results (Moore 2011a)

Significantly fewer participants required rescue medication with celecoxib than with placebo. The NNTs to prevent one patient remedicating within 24 hours were 4.8 for celecoxib $200 \mathrm{mg}$ and 3.5 for celecoxib $400 \mathrm{mg}$, but the difference was not significant ( $\mathrm{P}=$ 0.085). The median time to use of rescue medication varied greatly between trials, particularly for the active treatment arms, but was generally longer for celecoxib than 
placebo, and for celecoxib $400 \mathrm{mg}$ than celecoxib $200 \mathrm{mg}$. The weighted mean of the median time to use of rescue medication at 6.6 hours for celecoxib $200 \mathrm{mg}$ and 8.4 hours for celecoxib $400 \mathrm{mg}$ is longer than for some non-selective NSAIDs (ibuprofen $400 \mathrm{mg} 5.6$ hours, diclofenac $50 \mathrm{mg} 4.3$ hours), though not all (naproxen $500 \mathrm{mg} 8.9$ hours) but shorter than other coxibs (etoricoxib $120 \mathrm{mg} 20$ hours, rofecoxib $50 \mathrm{mg} 14$ hours, lumiracoxib nine hours). Longer duration of action is desirable in an analgesic, particularly in a postoperative setting where the patient may experience postoperative nausea or be dependent on a third party to respond to a request for rescue medication (or both). Duration of pain relief and requirement for rescue medication information have only recently been recognised as important outcomes (Moore 2005a), and a fuller evaluation of the importance of these outcomes will depend on more data being collected from other, ongoing, systematic reviews.

Assessment of adverse events is limited in single-dose studies as the size and duration of the trials permits only the simplest analysis, as has been emphasised previously (Edwards 1999b). There were insufficient data in these studies to compare individual adverse events. There was no significant difference between celecoxib and placebo for numbers of participants experiencing any adverse event in the hours immediately following a single dose of the study medication. Although all but one trial reported this outcome, combining results was potentially hampered by the different periods over which the data were collected. Most adverse events were reported as mild to moderate in intensity, and were most likely to be related to the anaesthetic or surgical procedure (e.g. nausea, vomiting, and somnolence). Serious adverse events and withdrawals due to adverse events occurred in both celecoxib and placebo treatment arms, but were uncommon and too few for any statistical analysis. It is important to recognise that adverse event analysis after single-dose oral administration will not reflect possible adverse events occurring with use of drugs for longer periods of time. In addition, the numbers of participants are insufficient to detect rare but serious adverse events.

\section{Overall completeness and applicability of evidence}

Included studies reported useful data for both primary and secondary outcomes, with the exception of Doyle 2002 for the primary outcome. Seven studies enrolled participants with dental pain following extraction of at least one impacted third molar. These individuals are generally in their early $20 \mathrm{~s}$, and are otherwise fit and healthy, so are clearly not representative of the range of individuals who might need analgesia for acute postoperative pain. There is no a priori reason why analgesic response in these individuals should differ in any systematic way from a more generalised population, but it is entirely possible that adverse events (gastrointestinal in particular) may be more frequent, intense, or severe in older patients, and those with comorbidities. The remaining study (Gimbel 2001) was carried out in patients with pain following uncomplicated orthopaedic surgery. The placebo response in this study was unusually high (21\%), which gave reduced efficacy, but it is impossible to speculate whether there is a real difference between pain conditions where there is only one study to consider. Differences between different pain models have either not been demonstrable in the past (Barden 2004), or have been possible to demonstrate only where there are an abundance of data (e.g. for ibuprofen; Derry C 2009b). 
There were no data available for lower doses of celecoxib, so conclusions/inferences about the benefit and harm of a lower dose cannot be made.

The unavailability of five completed randomised trials means that not all of the extant information on celecoxib in acute pain was available for analysis.

\section{Quality of the evidence}

All studies were of adequate methodological quality, with five scoring $5 / 5$ on the Oxford Quality Scale, and all administered the medication when pain levels were moderate or severe, ensuring that the study was sensitive to detect a $50 \%$ reduction.

\section{Potential biases in the review process}

We carried out a comprehensive search for relevant studies, and investigated the potential influence of publication bias by examining the number of participants in trials with zero effect (relative risk of 1.0) needed for the point estimate of the NNT to increase beyond a clinically useful level (Moore 2008). In this case, we chose a clinically useful level as 8 . For the primary outcome of at least 50\% pain relief with celecoxib $200 \mathrm{mg}$, about 640 participants would have to have been involved in unpublished trials with zero treatment effects for the NNT to increase above this threshold. For celecoxib $400 \mathrm{mg}$, twice as many (1360) participants in unpublished trials would be needed. Given that we know of five unpublished studies, it is possible, although unlikely, that these results could be overturned, although efficacy estimates could be changed.

\section{Agreements and disagreements with other studies or reviews}

We are not aware of any other systematic reviews of celecoxib in treating acute postoperative pain.

\section{AUTHORS' CONCLUSIONS}

\section{Implications for practice}

No new publications have been identified that provide data for analysis, so the conclusions of the previous review are unchanged. Celecoxib at its recommended dosage of $400 \mathrm{mg}$ for acute pain is an effective analgesic, equivalent to ibuprofen $400 \mathrm{mg}$, but providing a longer duration of pain relief than many traditional NSAIDs. Significantly fewer individuals achieve effective pain relief with celecoxib $200 \mathrm{mg}$ than with celecoxib $400 \mathrm{mg}$.

\section{Implications for research}

There are no major implications for research other than the possible benefits that are known to come from single-patient analysis, allowing different ways of reporting trial results which can be more useful to clinical practices (Edwards 1999a).

\section{Acknowledgments}

This update was supported by funds from the Oxford Pain Relief Trust. The first update was supported by the NHS Cochrane Collaboration Programme Grant Scheme. 
Jodie Barden, Jane Edwards, and Henry McQuay were involved in the earlier reviews.

SOURCES OF SUPPORT

Internal sources

- $\quad$ Oxford Pain Relief Trust, UK

External sources

- No sources of support supplied

\section{CHARACTERISTICS OF STUDIES}

\section{Characteristics of included studies [ordered by study ID]}

Cheung 2007

\begin{tabular}{|c|c|c|}
\hline Methods & \multicolumn{2}{|c|}{$\begin{array}{l}\text { RCT, DB single oral dose, } 3 \text { parallel groups } \\
\text { Medication administered when baseline pain reached a moderate to severe intensity } \\
\text { Pain assessed at } 0,15,30,45,60,90 \text { mins then hourly up to } 12 \mathrm{~h} \text {, and at } 16 \text { and } 24 \mathrm{~h}\end{array}$} \\
\hline Participants & \multicolumn{2}{|c|}{$\begin{array}{l}\text { Impacted third molar extraction } \\
\text { Mean age } 22 \text { years } \\
\mathrm{N}=171 \\
\mathrm{M}=77, \mathrm{~F}=94\end{array}$} \\
\hline Interventions & \multicolumn{2}{|c|}{$\begin{array}{l}\text { Celecoxib } 400 \mathrm{mg}, \mathrm{n}=57 \\
\text { Ibuprofen } 400 \mathrm{mg}, \mathrm{n}=57 \\
\text { Placebo, } \mathrm{n}=57\end{array}$} \\
\hline Outcomes & \multicolumn{2}{|c|}{$\begin{array}{l}\text { PI: std 4-point scale } \\
\text { PR: std 5-point scale } \\
\text { Time to use of rescue medication } \\
\text { Number of participants using rescue medication } \\
\text { Number of participants reporting any adverse event and serious adverse events } \\
\text { Number of participants withdrawing due to adverse event }\end{array}$} \\
\hline Notes & \multicolumn{2}{|c|}{$\begin{array}{l}\text { Oxford Quality Score: R2, DB2, W1 } \\
\text { Participants asked to refrain from rescue medication for } 1 \mathrm{~h}\end{array}$} \\
\hline \multicolumn{3}{|l|}{ Risk of bias } \\
\hline Bias & Authors' judgement & Support for judgement \\
\hline $\begin{array}{l}\text { Random sequence } \\
\text { generation (selection } \\
\text { bias) }\end{array}$ & Low risk & $\begin{array}{l}\text { "computer-generated randomization schedule, prepared before the start } \\
\text { of the study" }\end{array}$ \\
\hline $\begin{array}{l}\text { Allocation } \\
\text { concealment } \\
\text { (selection bias) }\end{array}$ & Low risk & $\begin{array}{l}\text { Medication supplied in patient-specific carton. Identity of assignment } \\
\text { contained in concealed section of label, which was removed at } \\
\text { dispensing, and attached to patient case report form }\end{array}$ \\
\hline $\begin{array}{l}\text { Blinding } \\
\text { (performance bias } \\
\text { and detection bias) } \\
\text { All outcomes }\end{array}$ & Low risk & $\begin{array}{l}\text { Double-blind method. Placebo capsules or tablets identical in number } \\
\text { and appearance to active treatments }\end{array}$ \\
\hline $\begin{array}{l}\text { Incomplete outcome } \\
\text { data (attrition bias) } \\
\text { All outcomes }\end{array}$ & Low risk & $\begin{array}{l}\text { All participants accounted for; analysis appropriate for relevant time } \\
\text { interval }\end{array}$ \\
\hline Other bias & Unclear risk & Small treatment group size (57 participants) \\
\hline
\end{tabular}

Doyle 2002 


\begin{tabular}{|c|c|c|}
\hline Methods & \multicolumn{2}{|c|}{$\begin{array}{l}\text { RCT, DB single oral and multiple oral dose, } 3 \text { parallel groups } \\
\text { Medication administered when baseline pain reached a moderate to severe intensity } \\
\text { Pain assessed at } 0,15,30,45,60,90 \text { mins then hourly up to } 12 \mathrm{~h}\end{array}$} \\
\hline Participants & \multicolumn{2}{|c|}{$\begin{array}{l}\text { Impacted third molar extraction } \\
\text { Mean age } 22 \text { years } \\
\mathrm{N}=174 \\
\mathrm{M}=75, \mathrm{~F}=99\end{array}$} \\
\hline Interventions & \multicolumn{2}{|c|}{$\begin{array}{l}\text { Celecoxib } 200 \mathrm{mg}, \mathrm{n}=74 \\
\text { Ibuprofen liquigel } 400 \mathrm{mg}, \mathrm{n}=74 \\
\text { Placebo, } \mathrm{n}=26\end{array}$} \\
\hline Outcomes & \multicolumn{2}{|c|}{$\begin{array}{l}\text { PI: 4-point scale } \\
\text { PR: 5-point scale } \\
\text { PGE: std 5-point scale (patients reporting "very good" or "excellent") } \\
\text { Time to use of rescue medication } \\
\text { Number of participants using rescue medication } \\
\text { Number of participants reporting any adverse event and serious adverse events } \\
\text { Number of participants withdrawing due to adverse event }\end{array}$} \\
\hline Notes & \multicolumn{2}{|c|}{$\begin{array}{l}\text { Oxford Quality Score: R2, DB2, W1 } \\
\text { Participants asked to refrain from rescue medication for } 1 \mathrm{~h}\end{array}$} \\
\hline \multicolumn{3}{|l|}{ Risk of bias } \\
\hline Bias & Authors' judgement & Support for judgement \\
\hline $\begin{array}{l}\text { Random sequence } \\
\text { generation } \\
\text { (selection bias) }\end{array}$ & Low risk & "computer-generated allocation schedule" \\
\hline $\begin{array}{l}\text { Allocation } \\
\text { concealment } \\
\text { (selection bias) }\end{array}$ & Unclear risk & Not described \\
\hline $\begin{array}{l}\text { Blinding } \\
\text { (performance bias } \\
\text { and detection bias) } \\
\text { All outcomes }\end{array}$ & Low risk & $\begin{array}{l}\text { Double-dummy method. "The appearance, presentation and labelling of } \\
\text { the placebo formulations were identical to those of the corresponding } \\
\text { active drugs" }\end{array}$ \\
\hline $\begin{array}{l}\text { Incomplete } \\
\text { outcome data } \\
\text { (attrition bias) } \\
\text { All outcomes }\end{array}$ & Low risk & Participants accounted for; analysis appropriate for relevant time interval \\
\hline Other bias & High risk & Small treatment group size (74 active, 26 placebo participants) \\
\hline
\end{tabular}

Fricke 2008

\begin{tabular}{ll}
\hline Methods & $\begin{array}{l}\text { RCT, DB, double-dummy, single oral dose, } 3 \text { parallel groups } \\
\text { Medication administered when baseline pain reached a moderate to severe intensity } \\
\text { Pain assessed at } 0,15,30,45,60,90 \text { mins then hourly up to } 12 \mathrm{~h}, \text { and at } 24 \mathrm{~h}\end{array}$ \\
\hline Participants & Impacted third molar extraction \\
& Mean age 23 years \\
& $\mathrm{N}=364$ \\
& $\mathrm{M}=133, \mathrm{~F}=231$ \\
\hline Interventions & Celecoxib $400 \mathrm{mg}, \mathrm{n}=156$ \\
& Lumiracoxib $400 \mathrm{mg}, \mathrm{n}=156$ \\
& Placebo, $\mathrm{n}=52$ \\
\hline Outcomes & PI: std 4-point scale \\
& PR: std 5-point scale \\
& Time to use of rescue medication \\
& Number of participants using rescue medication \\
& Number of participants reporting any adverse event and serious adverse events \\
& Number of participants withdrawing due to adverse event \\
\hline
\end{tabular}

Cochrane Database Syst Rev. Author manuscript; available in PMC 2014 September 11. 


\begin{tabular}{lll} 
Notes & $\begin{array}{l}\text { Oxford Quality Score: R2, DB1, W1 } \\
\text { Participants permitted to use rescue medication at any time }\end{array}$ \\
\hline Risk of bias & & \\
\hline Bias & Authors' judgement & Support for judgement \\
\hline $\begin{array}{l}\text { Random sequence } \\
\text { generation (selection } \\
\text { bias) }\end{array}$ & Low risk & Computer-generated \\
\hline $\begin{array}{l}\text { Allocation } \\
\text { concealment } \\
\text { (selection bias) }\end{array}$ & Low risk & Remote, automated allocation to randomisation numbers \\
\hline $\begin{array}{l}\text { Blinding } \\
\text { (performance bias and } \\
\text { detection bias) } \\
\text { All outcomes }\end{array}$ & Unclear risk & Not described \\
\hline $\begin{array}{l}\text { Incomplete outcome } \\
\text { data (attrition bias) } \\
\text { All outcomes }\end{array}$ & Low risk & $\begin{array}{l}\text { Participants accounted for; analysis appropriate for relevant time } \\
\text { interval }\end{array}$ \\
\hline \begin{tabular}{l} 
Other bias \\
\hline
\end{tabular} & Unclear risk & Small treatment group size (156 active, 52 placebo participants) \\
\hline
\end{tabular}

Gimbel 2001

\begin{tabular}{|c|c|c|}
\hline Methods & \multicolumn{2}{|c|}{$\begin{array}{l}\text { RCT, DB single oral and multiple oral dose, } 3 \text { parallel groups } \\
\text { Medication administered when baseline pain reached a moderate to severe intensity } \\
\text { Pain assessed at } 0,15,30,45,60,90 \text { mins then hourly up to } 8 \mathrm{~h} \text {. Multiple-dose phase } \\
\text { continued over } 3 \text { days }\end{array}$} \\
\hline Participants & \multicolumn{2}{|c|}{$\begin{array}{l}\text { Orthopaedic surgery (uncomplicated) } \\
\text { Mean age } 46 \text { years } \\
\mathrm{N}=418 \\
\mathrm{M}=165, \mathrm{~F}=253\end{array}$} \\
\hline Interventions & \multicolumn{2}{|c|}{$\begin{array}{l}\text { Celecoxib } 200 \mathrm{mg}, \mathrm{n}=141 \\
\text { Hydrocodone } 10 \mathrm{mg}+\text { acetaminophen } 1000 \mathrm{mg}, \mathrm{n}=136 \\
\text { Placebo, } \mathrm{n}=141\end{array}$} \\
\hline Outcomes & \multicolumn{2}{|c|}{$\begin{array}{l}\text { PI: std 4-point scale } \\
\text { PR: std 5-point scale } \\
\text { Time to use of rescue medication } \\
\text { Number of participants using rescue medication } \\
\text { Number of participants reporting any adverse event and serious adverse events } \\
\text { Number of participants withdrawing due to adverse event }\end{array}$} \\
\hline Notes & \multicolumn{2}{|c|}{$\begin{array}{l}\text { Oxford Quality Score: R1, DB1, W1 } \\
\text { Participants permitted to use rescue medication at any time }\end{array}$} \\
\hline \multicolumn{3}{|l|}{ Risk of bias } \\
\hline Bias & Authors' judgement & Support for judgement \\
\hline $\begin{array}{l}\text { Random sequence } \\
\text { generation (selection } \\
\text { bias) }\end{array}$ & Unclear risk & Not described \\
\hline $\begin{array}{l}\text { Allocation } \\
\text { concealment } \\
\text { (selection bias) }\end{array}$ & Unclear risk & Not described \\
\hline $\begin{array}{l}\text { Blinding } \\
\text { (performance bias } \\
\text { and detection bias) } \\
\text { All outcomes }\end{array}$ & Unclear risk & Not described \\
\hline $\begin{array}{l}\text { Incomplete outcome } \\
\text { data (attrition bias) } \\
\text { All outcomes }\end{array}$ & Low risk & $\begin{array}{l}\text { Participants accounted for; analysis appropriate for relevant time } \\
\text { interval }\end{array}$ \\
\hline
\end{tabular}


Kellstein 2004

\begin{tabular}{|c|c|c|}
\hline Methods & \multicolumn{2}{|c|}{$\begin{array}{l}\text { RCT, DB, double-dummy, single oral dose, } 4 \text { parallel groups } \\
\text { Medication administered when baseline pain reached a moderate to severe intensity } \\
\text { Pain assessed at } 0,15,30,45,60,90 \text { mins then hourly up to } 12 \mathrm{~h} \text {, and at } 24 \mathrm{~h}\end{array}$} \\
\hline Participants & \multicolumn{2}{|c|}{$\begin{array}{l}\text { Impacted third molar extraction } \\
\text { Mean age } 22 \text { years } \\
\mathrm{N}=355 \\
\mathrm{M}=112, \mathrm{~F}=243\end{array}$} \\
\hline Interventions & \multicolumn{2}{|c|}{$\begin{array}{l}\text { Celecoxib } 200 \mathrm{mg}, \mathrm{n}=101 \\
\text { Lumiracoxib } 400 \mathrm{mg}, \mathrm{n}=101 \\
\text { Rofecoxib } 50 \mathrm{mg}, \mathrm{n}=102 \\
\text { Placebo, } \mathrm{n}=51\end{array}$} \\
\hline Outcomes & \multicolumn{2}{|c|}{$\begin{array}{l}\text { PI: std 4-point scale } \\
\text { PR: std 5-point scale } \\
\text { PGE: std 5-point scale } \\
\text { Time to use of rescue medication } \\
\text { Number of participants using rescue medication }\end{array}$} \\
\hline Notes & \multicolumn{2}{|c|}{$\begin{array}{l}\text { Oxford Quality Score: R1, DB2, W1 } \\
\text { Participants asked to refrain from rescue medication for } 1 \mathrm{~h}\end{array}$} \\
\hline \multicolumn{3}{|l|}{ Risk of bias } \\
\hline Bias & Authors' judgement & Support for judgement \\
\hline $\begin{array}{l}\text { Random sequence } \\
\text { generation (selection } \\
\text { bias) }\end{array}$ & Unclear risk & Not described \\
\hline $\begin{array}{l}\text { Allocation } \\
\text { concealment } \\
\text { (selection bias) }\end{array}$ & Unclear risk & Not described \\
\hline $\begin{array}{l}\text { Blinding } \\
\text { (performance bias and } \\
\text { detection bias) } \\
\text { All outcomes }\end{array}$ & Low risk & $\begin{array}{l}\text { Double-dummy method. Placebo capsules and tablets matching } \\
\text { corresponding active treatments }\end{array}$ \\
\hline $\begin{array}{l}\text { Incomplete outcome } \\
\text { data (attrition bias) } \\
\text { All outcomes }\end{array}$ & Low risk & $\begin{array}{l}\text { Participants accounted for; analysis appropriate for relevant time } \\
\text { interval }\end{array}$ \\
\hline Other bias & Unclear risk & $\begin{array}{l}\text { Small treatment group size ( } 100 \text { to } 101 \text { active, } 51 \text { placebo } \\
\text { participants) }\end{array}$ \\
\hline
\end{tabular}

Malmstrom 1999

\begin{tabular}{ll}
\hline Methods & RCT, DB single oral dose and multiple oral dose, 4 parallel groups \\
& Medication administered when baseline pain reached a moderate to severe intensity \\
& Pain assessed at $0,15,30,45,60$, and 90 mins, then at $2,3,4,5,6,7,8 \mathrm{~h}$ \\
\hline Participants & Impacted third molar extraction \\
& Mean age 23 years \\
& $\mathrm{N}=272$ \\
& $\mathrm{M}=100, \mathrm{~F}=172$ \\
\hline Interventions & Celecoxib $200 \mathrm{mg}, \mathrm{n}=91$ \\
& Rofecoxib $50 \mathrm{mg}, \mathrm{n}=90$ \\
& Ibuprofen $400 \mathrm{mg}, \mathrm{n}=46$ \\
& Placebo, $\mathrm{n}=45$ \\
\hline
\end{tabular}




\begin{tabular}{lll} 
Outcomes & $\begin{array}{l}\text { PI: std 4-point scale } \\
\text { PR: std 5-point scale } \\
\text { PGE: std 5-point scale } \\
\text { Time to use of rescue medication } \\
\text { Number of participants using rescue medication }\end{array}$ \\
\hline Notes & $\begin{array}{l}\text { Oxford Quality Score: R2, DB2, W1 } \\
\text { Participants asked to refrain from rescue medication for 1.5 h }\end{array}$ \\
\hline Risk of bias & Authors' judgement & Support for judgement \\
\hline Bias & "computer-generated allocation schedule" \\
\hline $\begin{array}{l}\text { Random sequence } \\
\text { generation } \\
\text { (selection bias) }\end{array}$ & Low risk & Not described \\
\hline $\begin{array}{l}\text { Allocation } \\
\text { concealment } \\
\text { (selection bias) }\end{array}$ & Unclear risk & $\begin{array}{l}\text { Double-dummy method, using marketed tablet or capsule formulations } \\
\text { or matching placebos }\end{array}$ \\
\hline $\begin{array}{l}\text { Blinding } \\
\text { (performance bias } \\
\text { and detection bias) } \\
\text { All outcomes }\end{array}$ & Low risk & $\begin{array}{l}\text { Participants accounted for; analysis appropriate for relevant time } \\
\text { interval }\end{array}$ \\
\hline $\begin{array}{l}\text { Incomplete } \\
\text { outcome data } \\
\text { (attrition bias) } \\
\text { All outcomes }\end{array}$ & Low risk & $\begin{array}{l}\text { Small treatment group size (90, 91 coxib, 45,46 ibuprofen, and placebo } \\
\text { participants) }\end{array}$ \\
\hline $\begin{array}{l}\text { Other bias } \\
\text { High risk }\end{array}$ & & \\
\hline
\end{tabular}

\section{Malmstrom 2002}

\begin{tabular}{|c|c|c|}
\hline Methods & \multicolumn{2}{|c|}{$\begin{array}{l}\text { RCT, DB single oral dose, } 5 \text { parallel groups } \\
\text { Medication administered when baseline pain reached a moderate to severe intensity } \\
\text { Pain assessed at } 0,15,30,45,60 \text {, and } 90 \text { mins, then at } 2,3,4,5,6,7,8 \text {, and } 12 \mathrm{~h}\end{array}$} \\
\hline Participants & \multicolumn{2}{|c|}{$\begin{array}{l}\text { Impacted third molar extraction } \\
\text { Mean age } 22 \text { years } \\
\mathrm{N}=482 \\
\mathrm{M}=124, \mathrm{~F}=358\end{array}$} \\
\hline Interventions & \multicolumn{2}{|c|}{$\begin{array}{l}\text { Celecoxib } 400 \mathrm{mg}, \mathrm{n}=151 \\
\text { Celecoxib } 200 \mathrm{mg}, \mathrm{n}=90 \\
\text { Rofecoxib } 50 \mathrm{mg}, \mathrm{n}=150 \\
\text { Ibuprofen } 400 \mathrm{mg}, \mathrm{n}=45 \\
\text { Placebo, } \mathrm{n}=45\end{array}$} \\
\hline Outcomes & \multicolumn{2}{|c|}{$\begin{array}{l}\text { PI: std 4-point scale } \\
\text { PR: std 5-point scale } \\
\text { PGE: std 5-point scale } \\
\text { Time to use of rescue medication } \\
\text { Number of participants using rescue medication }\end{array}$} \\
\hline Notes & \multicolumn{2}{|c|}{$\begin{array}{l}\text { Oxford Quality Score: R2, DB2, W1 } \\
\text { Participants asked to refrain from rescue medication for } 1.5 \mathrm{~h}\end{array}$} \\
\hline \multicolumn{3}{|l|}{ Risk of bias } \\
\hline Bias & Authors' judgement & Support for judgement \\
\hline $\begin{array}{l}\text { Random sequence } \\
\text { generation } \\
\text { (selection bias) }\end{array}$ & Low risk & "computer-generated allocation schedule" \\
\hline $\begin{array}{l}\text { Allocation } \\
\text { concealment } \\
\text { (selection bias) }\end{array}$ & Low risk & $\begin{array}{l}\text { Participants allocated to next randomisation number (lowest for } \\
\text { moderate pain, highest for severe pain) }\end{array}$ \\
\hline
\end{tabular}

Cochrane Database Syst Rev. Author manuscript; available in PMC 2014 September 11. 


\begin{tabular}{lll}
$\begin{array}{l}\text { Blinding } \\
\text { (performance bias } \\
\text { and detection bias) } \\
\text { All outcomes }\end{array}$ & Low risk & $\begin{array}{l}\text { Double-dummy method. Each active treatment had matching placebo } \\
\text { tablets or capsules }\end{array}$ \\
\hline $\begin{array}{l}\text { Incomplete } \\
\text { outcome data } \\
\text { (attrition bias) } \\
\text { All outcomes }\end{array}$ & Low risk & Participants accounted for; analysis appropriate for relevant time interval \\
\hline Other bias & High risk & $\begin{array}{l}\text { Small treatment group size }(90 \text { to } 151 \text { coxib, } 45 \text { to } 50 \text { ibuprofen, and } \\
\text { placebo participants })\end{array}$ \\
\hline
\end{tabular}

Moberly 2007

\begin{tabular}{|c|c|c|}
\hline Methods & \multicolumn{2}{|c|}{$\begin{array}{l}\text { RCT, DB single oral dose, } 6 \text { parallel groups } \\
\text { Medication administered when baseline pain reached a moderate to severe intensity } \\
\text { Pain assessed at } 0,15,30,45,60 \text {, and } 90 \text { mins, then at } 2,3,4,5,6,7,8,10,12 \text {, and } 24 \mathrm{~h}\end{array}$} \\
\hline Participants & \multicolumn{2}{|c|}{$\begin{array}{l}\text { Impacted third molar extraction } \\
\text { Mean age } 22 \text { years } \\
\mathrm{N}=304 \\
\mathrm{M}=111, \mathrm{~F}=193\end{array}$} \\
\hline Interventions & \multicolumn{2}{|c|}{$\begin{array}{l}\text { Celecoxib } 400 \mathrm{mg}, \mathrm{n}=51 \\
\text { Placebo, } \mathrm{n}=52 \\
\text { CS-706 also tested at } 10,50,100,200 \mathrm{mg}\end{array}$} \\
\hline Outcomes & \multicolumn{2}{|c|}{$\begin{array}{l}\text { PI: std 4-point scale } \\
\text { PR: std 5-point scale } \\
\text { PGE: std 5-point scale } \\
\text { Time to use of rescue medication } \\
\text { Number of participants using rescue medication }\end{array}$} \\
\hline Notes & \multicolumn{2}{|c|}{$\begin{array}{l}\text { Oxford Quality Score: R1, DB2, W1 } \\
\text { Participants asked to refrain from rescue medication for } 1.5 \mathrm{~h}\end{array}$} \\
\hline \multicolumn{3}{|l|}{ Risk of bias } \\
\hline Bias & Authors' judgement & Support for judgement \\
\hline $\begin{array}{l}\text { Random sequence } \\
\text { generation (selection } \\
\text { bias) }\end{array}$ & Unclear risk & Not described \\
\hline $\begin{array}{l}\text { Allocation } \\
\text { concealment } \\
\text { (selection bias) }\end{array}$ & Low risk & $\begin{array}{l}\text { Investigator, all study staff and related personnel were unaware of } \\
\text { treatment assignment }\end{array}$ \\
\hline $\begin{array}{l}\text { Blinding } \\
\text { (performance bias } \\
\text { and detection bias) } \\
\text { All outcomes }\end{array}$ & Low risk & $\begin{array}{l}\text { Double-dummy method. Matching tablets for CS-706 and } \\
\text { corresponding placebo. Celecoxib and corresponding placebo capsules } \\
\text { differed in markings, so participant blindfolded and treatment } \\
\text { administered by a third party }\end{array}$ \\
\hline $\begin{array}{l}\text { Incomplete outcome } \\
\text { data (attrition bias) } \\
\text { All outcomes }\end{array}$ & Unclear risk & $\begin{array}{l}\text { Participants accounted for; analysis appropriate for relevant time } \\
\text { interval }\end{array}$ \\
\hline Other bias & Unclear risk & Small treatment group size (50 to 51 participants) \\
\hline
\end{tabular}

RCT - randomised controlled trial; R - randomisation; DB - double blind; W - withdrawals; PI - pain intensity; PR - pain relief; PGE - patient global evaluation; std - standard 


\section{Characteristics of excluded studies [ordered by study ID]}

\begin{tabular}{ll}
\hline Study & Reason for exclusion \\
\hline Salo 2003 & No placebo group; included participants with musculoskeletal injuries, not postoperative pain \\
\hline White 2007 & Not established moderate to severe pain \\
\hline
\end{tabular}

\section{Characteristics of studies awaiting assessment [ordered by study ID]}

177-CL-102

\begin{tabular}{ll}
\hline Methods & $\begin{array}{l}\text { Randomised, double-blind, parallel-group, duration 2 days } \\
\text { Medication given when pain } \geq \text { moderate }\end{array}$ \\
\hline Participants & $\begin{array}{l}\text { Postoperative pain } \\
\text { M and F, age } \geq 20 \text { years } \\
\end{array}$ \\
\hline \multirow{2}{*}{ Interventions 616}
\end{tabular}

ARRY-797-221

\begin{tabular}{l}
\hline Methods \\
\hline Participants \\
\hline Interventions \\
\hline Outcomes \\
\hline Notes $\quad$ Mentioned as "recently completed postoperative pain study" in ARRY-797-22 \\
\hline
\end{tabular}

ARRY-797-222

\begin{tabular}{ll}
\hline Methods & $\begin{array}{l}\text { Randomised, double-blind, single-dose, parallel-group, duration } 6 \mathrm{~h} \text { (to second dose) } \\
\text { Medication given when pain }>\text { moderate }\end{array}$ \\
\hline Participants & $\begin{array}{l}\text { Surgical removal of } \geq 3 \text { third molars (1 mandibular and impacted) } \\
\mathrm{M} \text { and F, age } 18 \text { to } 50 \text { years }\end{array}$ \\
& $\mathrm{N}=250$ \\
\hline Interventions & $\begin{array}{l}\text { Celecoxib } 400 \mathrm{mg} \\
\text { ARRY-31797 200mg } \\
\end{array}$ \\
& ARRY-31797 $400 \mathrm{mg}$ \\
& ARRY-31797 $600 \mathrm{mg}$ \\
& Placebo \\
\hline
\end{tabular}




\begin{tabular}{ll} 
Outcomes & $\begin{array}{l}\text { TOTPAR (dose 1) } \\
\text { Use of rescue medication } \\
\text { Adverse events }\end{array}$ \\
\hline Notes & Primary completion June 2008 \\
\hline
\end{tabular}

DIC2-08-03

\begin{tabular}{|c|c|}
\hline Methods & $\begin{array}{l}\text { Randomised, double-blind, single-dose, parallel-group, duration } 12 \mathrm{~h} \\
\text { Medication given when pain } \geq \text { moderate }\end{array}$ \\
\hline Participants & $\begin{array}{l}\text { Surgical removal of } \geq 2 \text { impacted third molars } \\
\mathrm{M} \text { and } \mathrm{F} \text {, age } 18 \text { to } 50 \text { years } \\
\mathrm{N}=202\end{array}$ \\
\hline Interventions & $\begin{array}{l}\text { Celecoxib } 400 \mathrm{mg} \\
\text { Diclofenac, lower dose } \\
\text { Diclofenac, higher dose } \\
\text { Placebo }\end{array}$ \\
\hline Outcomes & TOTPAR \\
\hline Notes & Primary completion December 2010 \\
\hline
\end{tabular}

IND2-08-03

\begin{tabular}{ll}
\hline Methods & $\begin{array}{l}\text { Randomised, double-blind, single-dose, parallel-group, duration } 8 \mathrm{~h} \\
\text { Medication given when pain } \geq \text { moderate }\end{array}$ \\
\hline Participants & $\begin{array}{l}\text { Surgical removal of } \geq 2 \text { impacted third molars } \\
\mathrm{M} \text { and } \mathrm{F}, \text { age } 18 \text { to } 50 \text { years } \\
\mathrm{N}=203\end{array}$ \\
\hline Interventions & $\begin{array}{l}\text { Celecoxib } 400 \mathrm{mg} \\
\text { Indomethacin, lower dose } \\
\end{array}$ \\
$\begin{array}{l}\text { Indomethacin, higher dose } \\
\text { Placebo }\end{array}$ \\
\hline Outcomes & TOTPAR \\
\hline Notes & Primary completion December 2010 \\
\hline
\end{tabular}

\section{Shirota 2001}

\begin{tabular}{ll}
\hline Methods \\
\hline Participants \\
\hline Interventions \\
\hline Outcomes \\
\hline Notes $\quad$ Awaiting translation (Chinese) \\
\hline
\end{tabular}


DATA AND ANALYSES

Comparison 1

Celecoxib $200 \mathrm{mg}$ versus placebo

\begin{tabular}{|c|c|c|c|c|}
\hline Outcome or subgroup title & No. of studies & No. of participants & Statistical method & Effect size \\
\hline $\begin{array}{l}1 \text { At least } 50 \% \text { pain relief } \\
\text { over } 4-6 \text { hours }\end{array}$ & 4 & 705 & $\begin{array}{l}\text { Risk Ratio (M-H, Fixed, } \\
95 \% \text { CI) }\end{array}$ & $3.49[2.40,5.06]$ \\
\hline 1.1 Dental pain & 3 & 423 & $\begin{array}{l}\text { Risk Ratio (M-H, Fixed, } \\
95 \% \text { CI) }\end{array}$ & $15.86[5.14,48.99]$ \\
\hline 1.2 Postsurgical pain & 1 & 282 & $\begin{array}{l}\text { Risk Ratio (M-H, Fixed, } \\
95 \% \text { CI) }\end{array}$ & $1.83[1.26,2.68]$ \\
\hline $\begin{array}{l}2 \text { Use of rescue medication } \\
\text { over } 24 \text { hours }\end{array}$ & 2 & 271 & $\begin{array}{l}\text { Risk Ratio (IV, Fixed, } \\
95 \% \text { CI) }\end{array}$ & $0.78[0.70,0.86]$ \\
\hline 3 Any adverse event & 4 & 669 & $\begin{array}{l}\text { Risk Ratio (M-H, Fixed, } \\
95 \% \text { CI) }\end{array}$ & $0.90[0.63,1.29]$ \\
\hline 3.1 Dental & 3 & 387 & $\begin{array}{l}\text { Risk Ratio (M-H, Fixed, } \\
95 \% \text { CI) }\end{array}$ & $0.97[0.63,1.49]$ \\
\hline 3.2 Orthopaedic & 1 & 282 & $\begin{array}{l}\text { Risk Ratio (M-H, Fixed, } \\
95 \% \text { CI) }\end{array}$ & $0.8[0.43,1.48]$ \\
\hline
\end{tabular}

Comparison 2

Celecoxib $400 \mathrm{mg}$ versus placebo

\begin{tabular}{lcclc}
\hline $\begin{array}{l}\text { Outcome or subgroup } \\
\text { title }\end{array}$ & No. of studies & No. of participants & \multicolumn{1}{c}{ Statistical method } & Effect size \\
\hline $\begin{array}{l}\text { 1 At least 50\% pain } \\
\text { relief over 4-6 hours, } \\
\text { dental pain }\end{array}$ & 4 & 620 & $\begin{array}{l}\text { Risk Ratio (M-H, Fixed, } \\
95 \% \text { CI) }\end{array}$ & 11.47 [5.85, 22.49] \\
$\begin{array}{l}\text { 2 Use of rescue } \\
\text { medication over 24 } \\
\text { hours }\end{array}$ & 3 & 518 & $\begin{array}{l}\text { Risk Ratio (IV, Fixed, 95\% } \\
\text { CI) }\end{array}$ & $0.68[0.62,0.74]$ \\
3 Any adverse event & 4 & & & $\begin{array}{l}\text { Risk Ratio (M-H, Fixed, } \\
95 \% \text { CI) }\end{array}$ \\
\hline
\end{tabular}




\section{Analysis 1.1}

Comparison 1 Celecoxib $200 \mathrm{mg}$ versus placebo, Outcome 1 At least 50\% pain relief over 4-6 hours

Review: Single dose oral celecoxib for acute postoperative pain in adults Comparison: 1 Celecoxib $200 \mathrm{mg}$ versus placebo Outcome: 1 At least 50\% pain relief over 4-6 hours

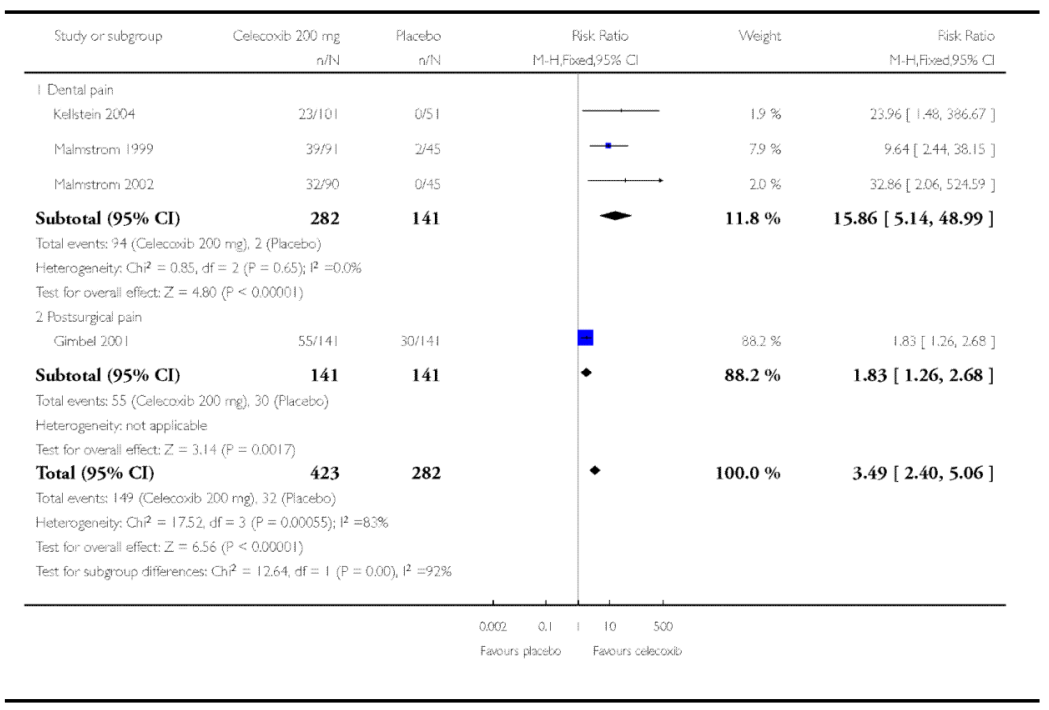

Analysis 1.2

Comparison 1 Celecoxib $200 \mathrm{mg}$ versus placebo, Outcome 2 Use of rescue medication over 24 hours

Review: Single dose oral celecoxib for acute postoperative pain in adults Comparison: 1 Celecoxib $200 \mathrm{mg}$ versus placebo

Outcome: 2 Use of rescue medication over 24 hours

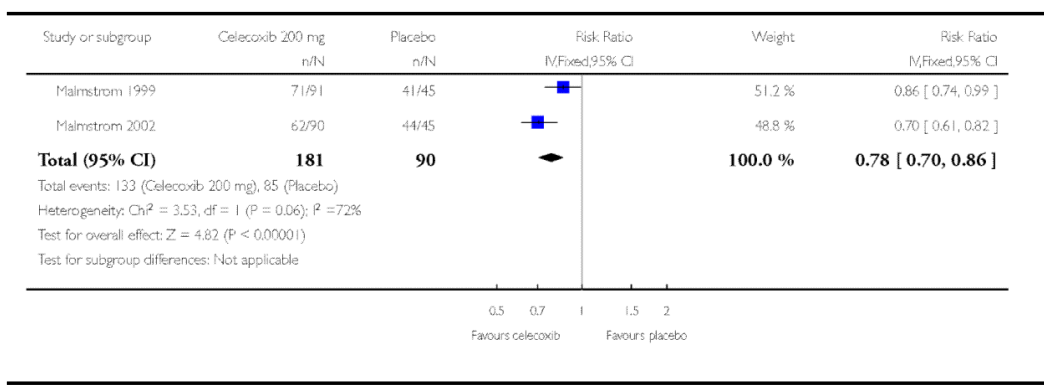


Analysis 1.3

Comparison 1 Celecoxib $200 \mathrm{mg}$ versus placebo, Outcome 3 Any adverse event

Review: Single dose oral celecoxib for acute postoperative pain in adults Comparison: 1 Celecoxib $200 \mathrm{mg}$ versus placebo Outcome: 3 Any adverse event

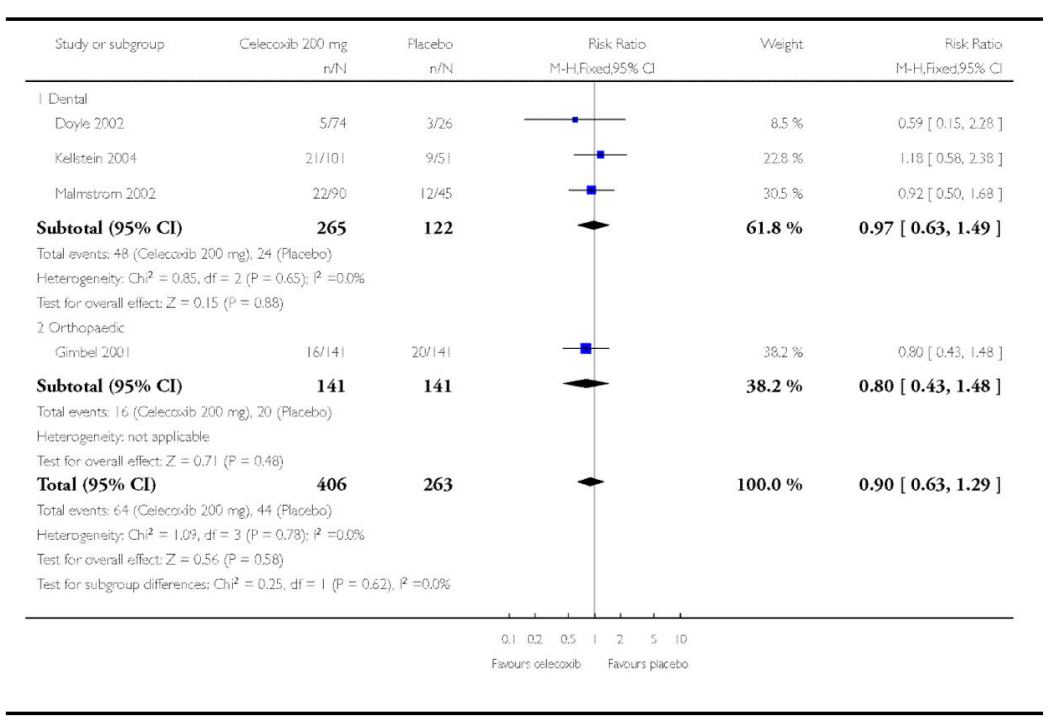

Analysis 2.1

Comparison 2 Celecoxib $400 \mathrm{mg}$ versus placebo, Outcome 1 At least 50\% pain relief over 4-6 hours, dental pain

Review: Single dose oral celecoxib for acute postoperative pain in adults Comparison: 2 Celecoxib $400 \mathrm{mg}$ versus placebo

Outcome: 1 At least 50\% pain relief over 4-6 hours, dental pain

\begin{tabular}{|c|c|c|c|c|c|c|}
\hline Study or subgroup & $\begin{array}{r}\text { Cedecorib } 400 \mathrm{mg} \\
\mathrm{rNAN}\end{array}$ & $\begin{array}{r}\text { Placetos } \\
\text { rilN }\end{array}$ & $M H, P$ & Risk Ratio & Weight & $\begin{array}{r}\text { Risk Patio } \\
\text { M. F. Fixed, } 95 \% \text { Cl }\end{array}$ \\
\hline Cheung 2007 & $36 / 57$ & 5,57 & & 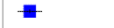 & $47.5 \%$ & $7,20[3,05,17,02]$ \\
\hline Fricke 2008 & $49 / 156$ & 0,52 & & $\longrightarrow$ & $7.1 \%$ & $33.42[2.10,532.45]$ \\
\hline Maimstrom 2002 & $74 / 151$ & $0 / 45$ & & $\longrightarrow$ & $73 \%$ & $45,09[2.85,713,49]$ \\
\hline Moberly 2007 & $25 / 51$ & 4,51 & & $=$ & $380 \%$ & $6.25[2.34,16.68]$ \\
\hline Total $(95 \% \mathrm{CI})$ & 415 & 205 & & - & $100.0 \%$ & $11.47[5.85,22.49]$ \\
\hline \multirow{3}{*}{\multicolumn{7}{|c|}{ 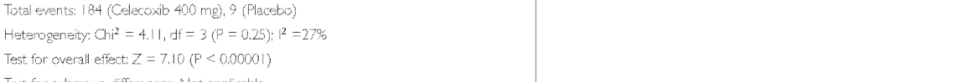 }} \\
\hline & & & & & & \\
\hline & & & & & & \\
\hline & & & 0,002 & 500 & & \\
\hline & & & Farous daction & Fowaris celectsotit & & \\
\hline
\end{tabular}




\section{Analysis 2.2}

Comparison 2 Celecoxib $400 \mathrm{mg}$ versus placebo, Outcome 2 Use of rescue medication over 24 hours

Review: Single dose oral celecoxib for acute postoperative pain in adults Comparison: 2 Celecoxib $400 \mathrm{mg}$ versus placebo Outcome: 2 Use of rescue medication over 24 hours

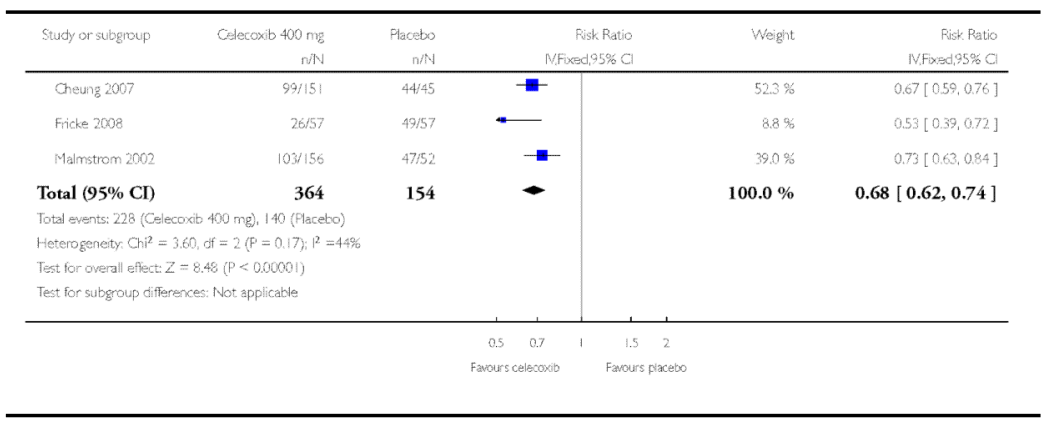

Analysis 2.3

Comparison 2 Celecoxib $400 \mathrm{mg}$ versus placebo, Outcome 3 Any adverse event

Review: Single dose oral celecoxib for acute postoperative pain in adults Comparison: 2 Celecoxib $400 \mathrm{mg}$ versus placebo Outcome: 3 Any adverse event

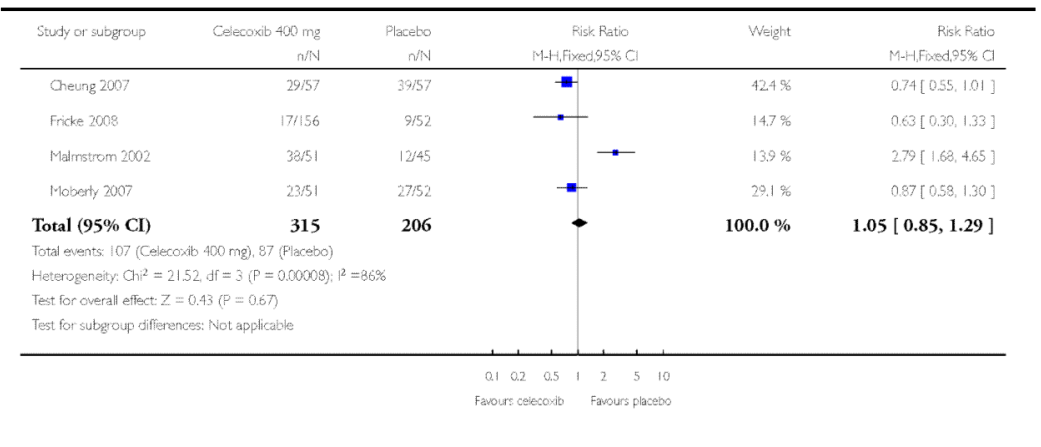

\section{Appendix 1. MEDLINE via OVID search strategy}

1. celecoxib.sh

2. (celecoxib OR celebrex OR Celebra OR Onsenal).ti.ab.kw.

3. 1 OR 2

4. PAIN, POSTOPERATIVE.sh

5. ((postoperative adj4 pain\$) or (post-operative adj4 pain\$) or post-operative-pain\$ or (post\$ NEAR pain\$) or (postoperative adj4 analgesi\$) or (post-perative adj4 analgesi\$) or (“post-operative analgesi\$”)).ti,ab,kw. 
6. ((post-surgical adj4 pain\$) or ("post surgical" adj4 pain\$) or (post-surgery adj4 pain\$)).ti,ab,kw.

7. ((“pain-relief after surg\$”) or ("pain following surg\$”) or ("pain control after")).ti,ab,kw.

8. ((“post surg\$” or post-surg\$) AND (pain\$ or discomfort)).ti,ab,kw.

9. ((pain\$ adj4 “after surg\$”) or (pain\$ adj4 “after operat\$”) or (pain\$ adj4 “follow\$ operat\$”) or (pain\$ adj4 “follow\$ surg\$”)).ti,ab,kw.

10. ((analgesi\$ adj4 “after surg\$”) or (analgesi\$ adj4 “after operat\$”) or (analgesi $\$$ adj4 “follow\$ operat\$”) or (analgesi\$ adj4 “follow\$ surg\$”)).ti,ab,kw.

11. $\mathrm{OR} / 4-10$

12. randomized controlled trial.pt.

13. controlled clinical trial.pt.

14. randomized.ab.

15. placebo.ab.

16. drug therapy.fs.

17. randomly.ab.

18. trial.ab.

19. groups.ab.

20. OR/12-19

21. 3 AND 11 AND 20

\section{Appendix 2. EMBASE via Ovid search strategy}

1. celecoxib.sh.

2. (celecoxib OR celebrex OR Celebra OR Onsenal).ti.ab.kw.

3. $\mathrm{OR} / 1-2$

4. PAIN, POSTOPERATIVE.sh.

5. ((postoperative adj4 pain\$) or (post-operative adj4 pain\$) or post-operative-pain\$ or (post\$ NEAR pain\$) or (postoperative adj4 analgesi\$) or (post-operative adj4 analgesi\$) or (“post-operative analgesi\$”)).ti.ab.kw.

6. ((post-surgical adj4 pain\$) or ("post surgical” adj4 pain\$) or (post-surgery adj4 pain\$)).ti.ab.kw.

7. (("pain-relief after surg\$”) or ("pain following surg\$”) or ("pain control after")).ti.ab.kw.

8. ((“post surg\$” or post-surg\$) AND (pain\$ or discomfort)).ti.ab.kw. 
9. ((pain\$ adj4 “after surg\$”) or (pain\$ adj4 "after operat\$”) or (pain\$ adj4 “follow\$ operat\$”) or (pain\$ adj4 “follow\$ surg\$”)).ti.ab.kw.

10. ((analgesi\$ adj4 “after surg\$”) or (analgesi\$ adj4 "after operat\$”) or (analgesi\$ adj4 “follow\$ operat\$”) or (analgesi\$ adj4 “follow\$ surg\$”)).ti.ab.kw.

11. $\mathrm{OR} / 4-10$

12. clinical trials.sh.

13. controlled clinical trials.sh.

14. randomized controlled trial.sh.

15. double-blind procedure.sh.

16. (clin\$ adj25 trial\$).ab.

17. ((doubl\$ or trebl\$ or tripl\$) adj25 (blind\$ or mask\$)).ab.

18. placebo\$.ab.

19. random\$.ab.

20. $\mathrm{OR} / 12-19$

21. 3 AND 11 AND 20

\section{Appendix 3. Cochrane CENTRAL search strategy}

1. MESH descriptor celecoxib

2. (celecoxib OR celebrexOR Celebra OR Onsenal):ti.ab.kw.

3. $\mathrm{OR} / 1-2$

4. MESH descriptor PAIN, POSTOPERATIVE

5. ((postoperative adj4 pain\$) or (post-operative adj4 pain\$) or post-operative-pain\$ or (post\$ NEAR pain\$) or (postoperative adj4 analgesi\$) or (post-operative adj4 analgesi\$) or (“post-operative analgesi\$”)):ti.ab.kw.

6. ((post-surgical adj4 pain\$) or ("post surgical” adj4 pain\$) or (post-surgery adj4 pain\$)):ti.ab.kw.

7. ((“pain-relief after surg\$”) or ("pain following surg\$”) or ("pain control after")):ti.ab.kw.

8. ((“post surg\$” or post-surg\$) AND (pain\$ or discomfort)):ti.ab.kw.

9. ((pain\$ adj4 “after surg\$”) or (pain\$ adj4 “after operat\$”) or (pain\$ adj4 “follow\$ operat\$”) or (pain\$ adj4 “follow\$ surg\$”)): ti.ab.kw.

10. ((analgesi\$ adj4 “after surg\$”) or (analgesi\$ adj4 "after operat\$”) or (analgesi\$ adj4 “follow\$ operat\$”) or (analgesi\$ adj4 “follow\$ surg\$”)):ti.ab.kw.

11. $\mathrm{OR} / 4-10$ 
12. Limit 11 to Clinical Trials (CENTRAL)

\section{Appendix 4. Glossary \\ Categorical rating scale}

The commonest is the five category scale (none, slight, moderate, good or lots, and complete). For analysis numbers are given to the verbal categories (for pain intensity, none $=0$, mild $=1$, moderate $=2$, and severe $=3$, and for relief none $=0$, slight $=1$, moderate $=2$, good or lots $=3$, and complete $=4$ ). Data from different subjects is then combined to produce means (rarely medians) and measures of dispersion (usually standard errors of means). The validity of converting categories into numerical scores was checked by comparison with concurrent visual analogue scale measurements. Good correlation was found, especially between pain relief scales using cross-modality matching techniques. Results are usually reported as continuous data, mean or median pain relief or intensity. Few studies present results as discrete data, giving the number of participants who report a certain level of pain intensity or relief at any given assessment point. The main advantages of the categorical scales are that they are quick and simple. The small number of descriptors may force the scorer to choose a particular category when none describes the pain satisfactorily.

\section{Visual analogue scale (VAS)}

Analogue scale: lines with left end labelled 'no relief of pain' and right end labelled 'complete relief of pain', seem to overcome this limitation. Patients mark the line at the point which corresponds to their pain. The scores are obtained by measuring the distance between the no relief end and the patient's mark, usually in millimetres. The main advantages of VAS are that they are simple and quick to score, avoid imprecise descriptive terms, and provide many points from which to choose. More concentration and coordination are needed, which can be difficult postoperatively or with neurological disorders.

\section{TOTPAR}

Total pain relief (TOTPAR) is calculated as the sum of pain relief scores over a period of time. If a patient had complete pain relief immediately after taking an analgesic, and maintained that level of pain relief for six hours, they would have a six-hour TOTPAR of the maximum of 24. Differences between pain relief values at the start and end of a measurement period are dealt with by the trapezoidal rule.

\section{SPID}

Summed pain intensity difference (SPID) is calculated as the sum of the differences between the pain scores over a period of time. Differences between pain intensity values at the start and end of a measurement period are dealt with by the trapezoidal rule.

VAS TOTPAR and VAS SPID are visual analogue versions of TOTPAR and SPID. 
See 'Measuring pain' in Bandolier's Little Book of Pain, Oxford University Press, Oxford. 2003; pp 7-13 (Moore 2003).

\section{Appendix 5. Summary of outcomes in individual studies: efficacy}




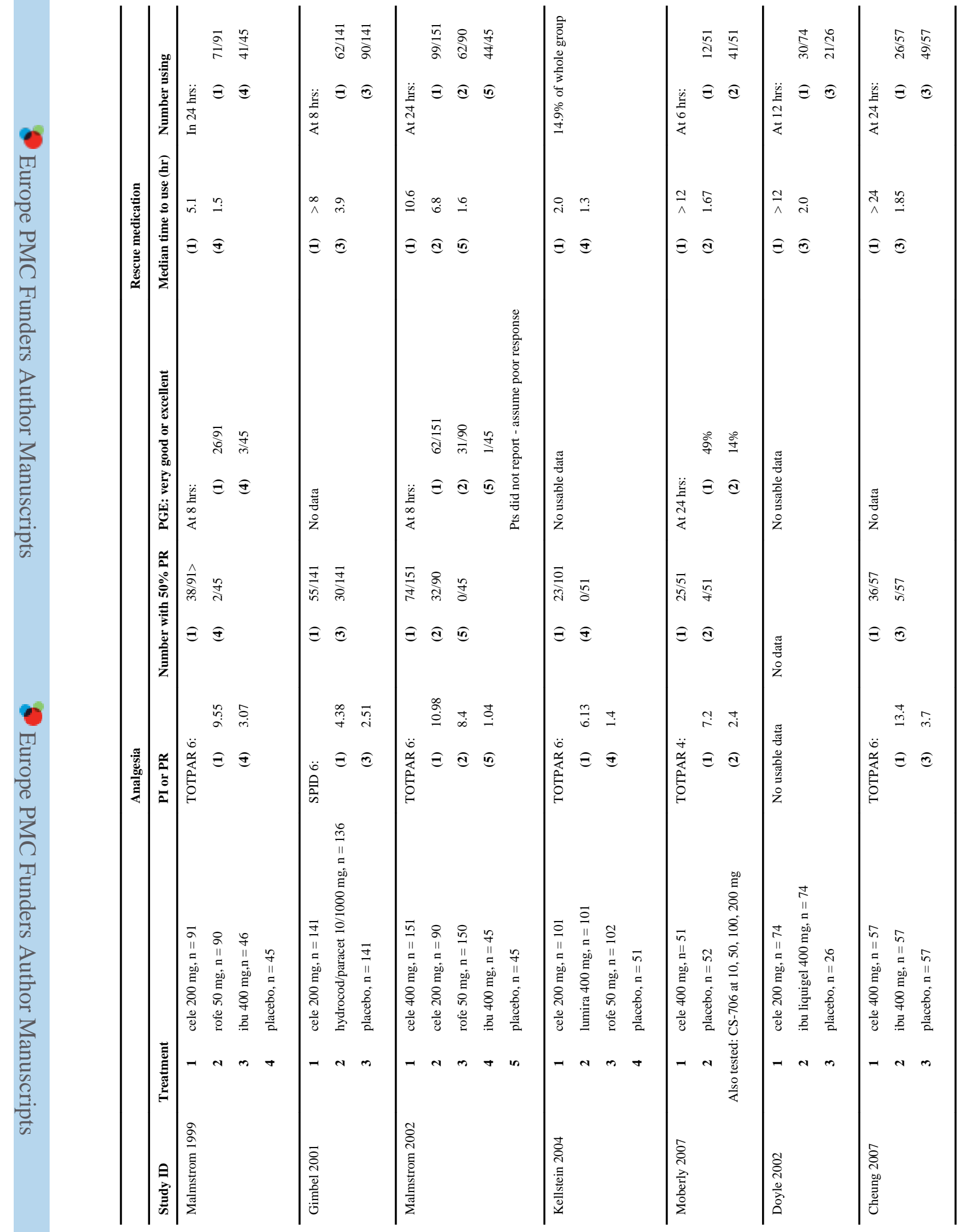




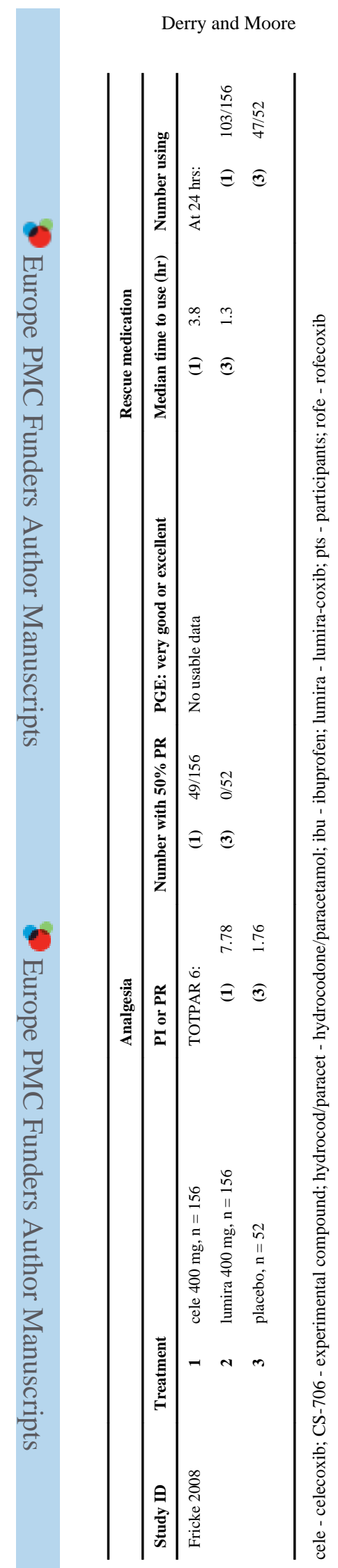

Page 33 
Appendix 6. Summary of outcomes in individual studies: adverse events and withdrawals 


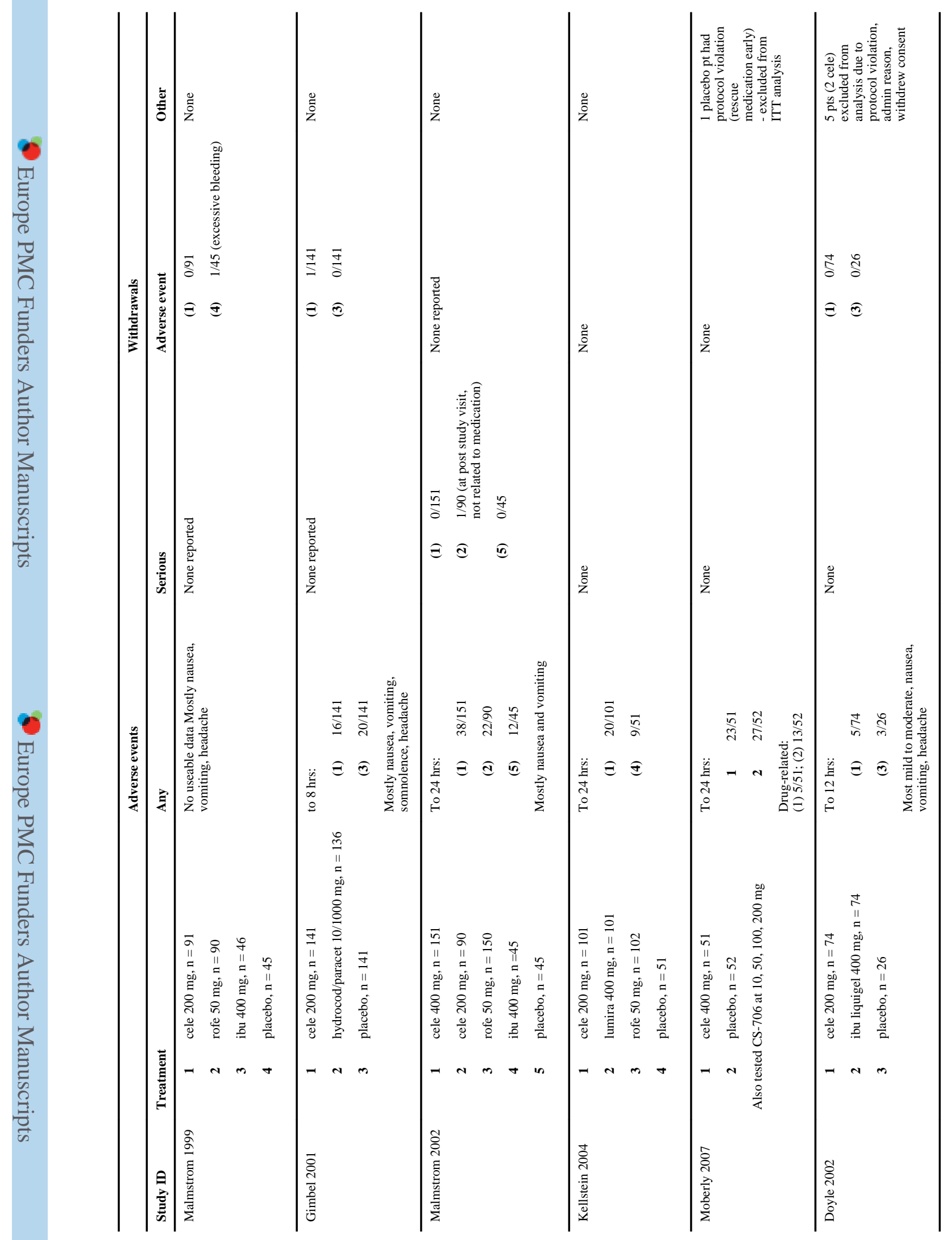




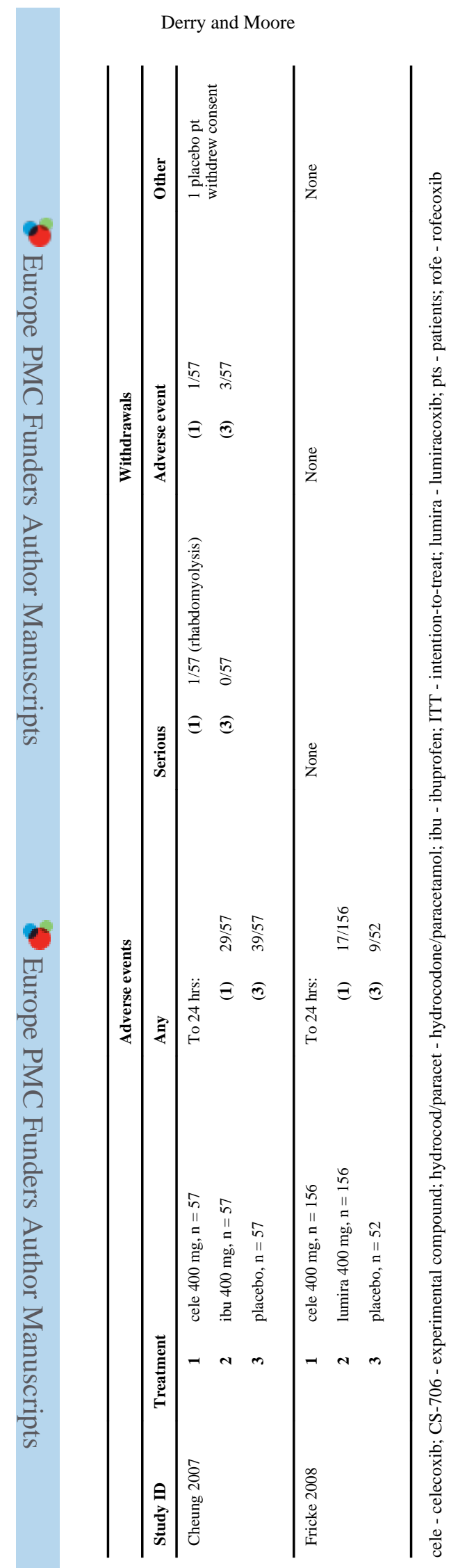

Cochrane Database Syst Rev. Author manuscript; available in PMC 2014 September 11. 


\section{Appendix 7. L'Abbé plots}

Improved with celecoxib $200 \mathrm{mg}(\%)$

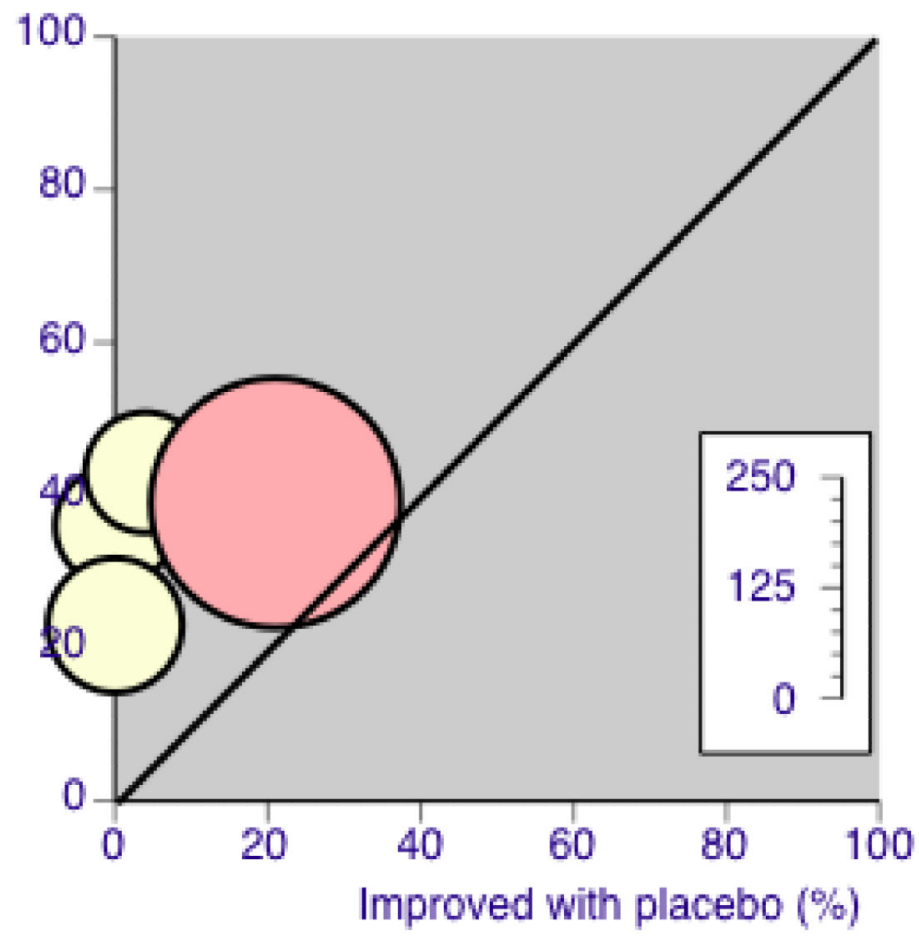

Figure 5. L'Abbé plot of celecoxib $200 \mathrm{mg}$ versus placebo for at least $50 \%$ pain relief. Size of circle is proportional to size of study (inset scale). Cream circles - dental studies; pink circle orthopaedic study 


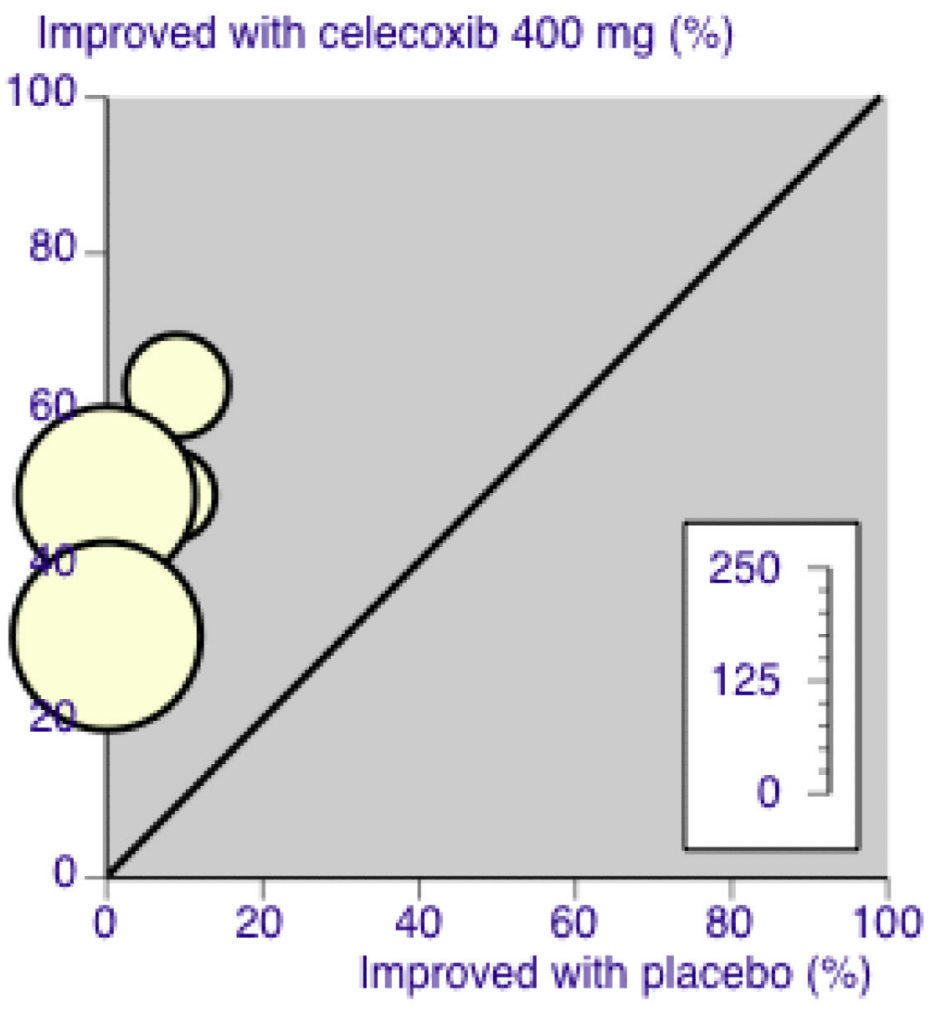

Figure 6. L'Abbé plot of celecoxib $400 \mathrm{mg}$ versus placebo for at least $50 \%$ pain relief. Size of circle is proportional to size of study (inset scale). Cream circles - dental studies

\section{WHAT'S NEW}

Last assessed as up-to-date: 3 January 2012.

\begin{tabular}{lll}
\hline Date & Event & Description \\
\hline 3 January 2012 & $\begin{array}{l}\text { New search has been } \\
\text { performed }\end{array}$ & $\begin{array}{l}\text { Searches updated. No new studies with available data identified. } \\
\text { Five potentially relevant, completed, but unpublished studies } \\
\text { identified; data not yet available. Conclusions unchanged }\end{array}$ \\
\hline 3 January 2012 & $\begin{array}{l}\text { New citation required but } \\
\text { conclusions have not changed }\end{array}$ & $\begin{array}{l}\text { The search for this review update was brought up to date to } \\
\text { January 2012 }\end{array}$ \\
\hline
\end{tabular}

\section{HISTORY}

Protocol first published: Issue 2, 2003

Review first published: Issue 2, 2003

\begin{tabular}{lll}
\hline Date & Event & Description \\
\hline 24 September 2010 & Amended & Contact details updated. \\
\hline
\end{tabular}




\begin{tabular}{lll}
\hline Date & Event & Description \\
\hline 7 November 2008 & Amended & Further RevMan 5 changes. \\
\hline 22 July 2008 & $\begin{array}{l}\text { New search has been } \\
\text { performed }\end{array}$ & This is an update of the original review published in Issue 2, 2003 \\
\hline 22 July 2008 & $\begin{array}{l}\text { New citation } \\
\text { required and } \\
\text { conclusions have } \\
\text { changed }\end{array}$ & $\begin{array}{l}\text { This review now contains data from eight studies using celecoxib 400mg } \\
\text { and 200mg (1380 participants), compared with two (418 participants) at } \\
\text { 200 mg previously. } \\
\text { In addition to the proportion of participants with at least 50\% pain relief } \\
\text { over six hours, the update collected information on median time to use of } \\
\text { rescue medication. This may be a more useful practical outcome }\end{array}$ \\
\hline
\end{tabular}

\section{References to studies included in this review}

Cheung 2007 \{published data only\} . Cheung R, Krishnaswami S, Kowalski K. Analgesic efficacy of celecoxib in postoperative oral surgery pain: a single-dose, two-center, randomized, doubleblind, active- and placebo-controlled study. Clinical Therapeutics. 2007; 29(Suppl):2498-510. [PubMed: 18164917]

Doyle 2002 \{published data only\} . Doyle G, Jayawardena S, Ashraf E, Cooper SA. Efficacy and tolerability of nonprescription ibuprofen versus celecoxib for dental pain. Journal of Clinical Pharmacology. 2002; 42(8):912-9. [PubMed: 12162474]

Fricke 2008 \{published data only\} . Fricke J, Davis N, Yu V, Krammer G. Lumiracoxib 400 mg compared with celecoxib $400 \mathrm{mg}$ and placebo for treating pain following dental surgery: a randomized, controlled trial. Journal of Pain. 2008; 9(1):20-7. [PubMed: 17933588]

Gimbel 2001 \{published data only\} . Gimbel JS, Brugger A, Zhao W, Verburg KM, Geis GS. Efficacy and tolerability of celecoxib versus hydrocodone/acetaminophen in the treatment of pain after ambulatory orthopedic surgery in adults. Clinical Therapeutics. 2001; 23(2):228-41. [PubMed: 11293556]

Kellstein 2004 \{published data only\} . Kellstein D, Ott D, Jayawardene S, Fricke J. Analgesic efficacy of a single dose of lumiracoxib compared with rofecoxib, celecoxib and placebo in the treatment of post-operative dental pain. International Journal of Clinical Practice. 2004; 58(3): 244-50. [PubMed: 15117090]

Malmstrom 1999 \{published data only\} . Malmstrom K, Daniels S, Kotey P, Seidenburg BC, Desjardins PJ. Comparison of rofecoxib and celecoxib, two cyclooxygenase-2 inhibitors, in postoperative dental pain: a randomised, placebo- and active-comparator-controlled clinical trial. Clinical Therapeutics. 1999; 21(10):1653-63. [PubMed: 10566562]

Malmstrom 2002 \{published data only\} . Malmstrom K, Fricke JR, Kotey P, Kress B, Morrison B. A comparison of rofecoxib versus celecoxib in treating pain after dental surgery: a single-center, randomized, double-blind, placebo- and active-comparator-controlled, parallel-group, single-dose study using the dental impaction pain model. Clinical Therapeutics. 2002; 24(10):1549-60.

[PubMed: 12462285]

Moberly 2007 \{published data only\} . Moberly JB, Xu J, Desjardins PJ, Daniels SE, Bandy DP, Lawson JE, et al. A randomized, double-blind, celecoxib- and placebo-controlled study of the effectiveness of CS-706 in acute postoperative dental pain. Clinical Therapeutics. 2007; 29(3): 399-412. [PubMed: 17577461]

\section{References to studies excluded from this review}

Salo 2003 \{published data only\} . Salo DF, Lavery R, Varma V, Goldberg J, Shapiro T, Kenwood A. A randomized, clinical trial comparing oral celecoxib $200 \mathrm{mg}$, celecoxib $400 \mathrm{mg}$, and ibuprofen $600 \mathrm{mg}$ for acute pain. Academic Emergency Medicine. 2003; 10:22-30. [PubMed: 12511311]

White 2007 \{published data only\} . White PF, Sacan O, Tufanogullari B, Eng M, Nuangchamnong $\mathrm{N}$, Ogunnaike B. Effect of short-term postoperative celecoxib administration on patient 
outcomeafter outpatient laparoscopic surgery. Canadian Journal of Anaesthesia. 2007; 54(5): 342-8. [PubMed: 17470884]

\section{References to studies awaiting assessment}

177-CL-102 \{unpublished data only\} . An etodolac- and placebo-controlled, multicenter, doubleblind, group comparison study to verify the efficacy of YM177 (Celecoxib) in postoperative pain patients. CTG: NCT01118572

ARRY-797-221 \{unpublished data only\}

ARRY-797-222 \{unpublished data only\} . A randomized, double-blind, placebo- and activecontrolled, parallel-group analgesic efficacy trial of oral ARRY-371797 in subjects undergoing third molar extraction. CTG: NCT00663767

DIC2-08-03 \{unpublished data only\} . A phase 2, randomized, double-blind, single-dose, parallelgroup, active- and placebo-controlled study of diclofenac [Test] capsules for the treatment of pain after surgical removal of impacted third molars. CTG: NCT00985439

IND2-08-03 \{unpublished data only\} . A phase 2, randomized, double-blind, single-dose, parallelgroup, active- and placebo-controlled study of indomethacin test capsules for the treatment of pain after surgical removal of impacted third molars. CTG: NCT00964431

Shirota 2001 \{published data only\}. Shirota T, Ohno K-S, Michii K-I, Kamijo R, Nagumo M, Sato H, et al. A study of the dose-response of YM177 for treatment of postsurgical dental pain. Oral Therapeutics and Pharmacology. 2001; 20(3):154-72.

\section{Additional references}

Barden 2004 . Barden J, Edwards JE, McQuay HJ, Andrew Moore R. Pain and analgesic response after third molar extraction and other postsurgical pain. Pain. 2004; 107(1-2):86-90. DOI: 10.1016/j.pain.2003.09.021. [PubMed: 14715393]

Clarke 2012 . Clarke R, Derry S, Moore RA, McQuay HJ. Single dose oral etoricoxib for postoperative pain. Cochrane Database of Systematic Reviews. 2012 Issue in press.

Collins 1997 . Collins SL, Moore RA, McQuay HJ. The visual analogue pain intensity scale: what is moderate pain in millimetres? Pain. 1997; 72:95-7. [PubMed: 9272792]

Collins 2001 . Collins SL, Edwards J, Moore RA, Smith LA, McQuay HJ. Seeking a simple measure of analgesia for mega-trials: is a single global assessment good enough? Pain. 2001; 91:189-94. [PubMed: 11240091]

Cook 1995 . Cook RJ, Sackett DL. The number needed to treat: a clinically useful measure of treatment effect. BMJ. 1995; 310:452-4. [PubMed: 7873954]

Cooper 1991 . Cooper, SA. Single-dose analgesic studies: the upside and downside of assay sensitivity. In: Max, MB.; Portenoy, RK.; Laska, EM., editors. The Design of Analgesic ClinicalTrials. Advances in Pain Research and Therapy. Vol. 18. Raven Press; New York: 1991. p. 117-24.

Derry 2011 . Derry S, Wiffen PJ, Moore RA. Relative efficacy of oral analgesics after third molar extraction - a 2011 update. British Dental Journal. 2011; 211(9):419-20. DOI: 10.1038/sj.bdj. 2011.905. [PubMed: 22075882]

Derry 2012 . Derry S, Moore RA. Single dose oral aspirin for acute postoperative pain in adults. Cochrane Database of Systematic Reviews. 2012 Issue in press.

Derry C 2009a . Derry C, Derry S, Moore RA, McQuay HJ. Single dose oral naproxen and naproxen sodium for acute postoperative pain in adults. Cochrane Database of Systematic Reviews. 2009;

(1) DOI: 10.1002/14651858.CD004234.pub2.

Derry C 2009b . . Derry C, Derry S, Moore RA, McQuay HJ. Single dose oral ibuprofen for acute postoperative pain in adults. Cochrane Database of Systematic Reviews. 2009; (3) DOI: 10.1002/14651858.CD001548.pub2.

Derry P 2009 . Derry P, Derry S, Moore RA, McQuay HJ. Single dose oral diclofenac for acute postoperative pain in adults. Cochrane Database of Systematic Reviews. 2009; (2) DOI: 10.1002/14651858.CD004768.pub2. 
Edwards 1999a . Edwards JE, Oldman AD, Smith LA, Carroll D, Wiffen PJ, McQuay HJ, et al. Oral aspirin in postoperative pain: a quantitative systematic review. Pain. 1999; 81:289-97. [PubMed: 10431716]

Edwards 1999b . Edwards JE, McQuay HJ, Moore RA, Collins SL. Reporting of adverse effects in clinical trials should be improved: lessons from acute postoperative pain. Journal of Pain and Symptom Management. 1999; 18(6):427-37. [PubMed: 10641469]

Garner 2002 . Garner S, Fidan D, Frankish R, Judd M, Towheed T, Wells G, et al. Rofecoxib for the treatment of rheumatoid arthritis. Cochrane Database of Systematic Reviews. 2002; (2) DOI: 10.1002/14651858.CD003685.pub2.

Grahame-Smith 2002 . Grahame-Smith, DG.; Aronson, JK. Oxford Textbook of Clinical Pharmacology and Drug Therapy. 3rd Edition. Oxford University Press; Oxford: 2002.

Hawkey 1999 . Hawkey CJ. Cox-2 inhibitors. Lancet. 1999; 353(9149):307-14. [PubMed: 9929039]

Hawkey 2001 . Hawkey CJ. Gastrointestinal safety of COX-2 specific inhibitors. Gastroenterology Clinics of North America. 2001; 30(4):921-36. [PubMed: 11764535]

Jadad 1996a . Jadad A, Carroll D, Moore RA, McQuay HJ. Developing a database of published reports of randomised clinical trials in pain research. Pain. 1996; 66:239-46. [PubMed: 8880846]

Jadad 1996b . Jadad AR, Moore RA, Carroll D, Jenkinson C, Reynolds DJM, Gavaghan DJ, et al. Assessing the quality of reports of randomized clinical trials: is blinding necessary? Controlled Clinical Trials. 1996; 17:1-12. [PubMed: 8721797]

L'Abbé 1987 . L'Abbé KA, Detsky AS, O'Rourke K. Meta-analysis in clinical research. Annals of Internal Medicine. 1987; 107:224-33. [PubMed: 3300460]

McQuay 2005 . McQuay HJ, Moore RA. Placebo. Postgraduate Medical Journal. 2005; 81:155-60. [PubMed: 15749790]

Moher 1999 . Moher D, Cook DJ, Eastwood S, Olkin I, Rennie D, Stroup DF. Improving the quality of reports of meta-analyses of randomised controlled trials: the QUOROM statement. Quality of Reporting of Meta-analyses. Lancet. 1999; 27(354):1896-900. [PubMed: 10584742]

Moore 1996 . Moore A, McQuay H, Gavaghan D. Deriving dichotomous outcome measures from continuous data in randomised controlled trials of analgesics. Pain. 1996; 66(2-3):229-37. [PubMed: 8880845]

Moore 1997a . Moore A, McQuay H, Gavaghan D. Deriving dichotomous outcome measures from continuous data in randomised controlled trials of analgesics: verification from independent data. Pain. 1997; 69(1-2):127-30. [PubMed: 9060022]

Moore 1997b . Moore A, Moore O, McQuay H, Gavaghan D. Deriving dichotomous outcome measures from continuous data in randomised controlled trials of analgesics: use of pain intensity and visual analogue scales. Pain. 1997; 69(3):311-5. [PubMed: 9085306]

Moore 1998 . Moore RA, Gavaghan D, Tramer M, Collins SL, McQuay HJ. Size is everything large amounts of information are needed to overcome random effects in estimating direction and magnitude of treatment effects. Pain. 1998; 78(3):209-16. [PubMed: 9870574]

Moore 2003 . Moore, RA.; Edwards, J.; Barden, J.; McQuay, HJ. Bandolier's Little Book of Pain. Oxford University Press; Oxford: 2003.

Moore 2005a . Moore RA, Edwards JE, McQuay HJ. Acute pain: individual patient meta-analysis shows the impact of different ways of analysing and presenting results. Pain. 2005; 116(3):32231. [PubMed: 15979792]

Moore 2005b . Moore RA, Derry S, Makinson GT, McQuay HJ. Tolerability and adverse events in clinical trials of celecoxib in osteoarthritis and rheumatoid arthritis: systematic review and metaanalysis of information from company clinical trial reports. Arthritis Research and Therapy. 2005; 7(3):R644-65. [PubMed: 15899051]

Moore 2006 . Moore, A.; McQuay, H. Bandolier's Little Book of Making Sense of the Medical Evidence. Oxford University Press; Oxford: 2006.

Moore 2008 . Moore, RA.; Barden, J.; Derry, S.; McQuay, HJ. Managing potential publication bias. In: McQuay, HJ.; Kalso, E.; Moore, RA., editors. Systematic Reviews in Pain Research: Methodology Refined. IASP Press; Seattle: 2008. p. 15-24.ISBN: 978-0-931092-69-5 
Moore 2011a . Moore RA, Derry S, McQuay HJ, Wiffen PJ. Single dose oral analgesics for acute postoperative pain in adults. Cochrane Database of Systematic Reviews. 2011; (9) DOI: 10.1002/14651858.CD008659.pub2.

Moore 2011b . Moore RA, Straube S, Paine J, Derry S, McQuay HJ. Minimum efficacy criteria for comparisons between treatments using individual patient meta-analysis of acute pain trials: examples of etoricoxib, paracetamol, ibuprofen, and ibuprofen/paracetamol combinations after third molar extraction. Pain. 2011; 152(5):982-9. DOI: doi:10.1016/j.pain.2010.11.030. [PubMed: 21414722]

Morris 1995 . Morris, JA.; Gardner, MJ. Calculating confidence intervals for relative risk, odds ratio and standardised ratios and rates. In: Gardner, MJ.; Altman, DG., editors. Statistics with Confidence. British Medical Journal; London: 1995. p. 50-63.

NLM 2002 . National Institutes for Health. [accessed May 2002] National Library of Medicine. www.nlm.nih.gov/medlineplus/druginfo/celecoxibsystemic203736.html

PACT 2010 . The NHS Information Centre for Health and Social Care. 2010. Prescription Cost Analysis England. ISBN: 978-1-84636-542-3

Patrono 2009 . Patrono C, Baigent C. Low-dose aspirin, coxibs, and other NSAIDS: a clinical mosaic emerges. Molecular Interventions. 2009; 9(1):31-9. [PubMed: 19299662]

RevMan 2011 . The Nordic Cochrane Centre. The Cochrane Collaboration. Review Manager (RevMan). 5.1. The Nordic Cochrane Centre, The Cochrane Collaboration; Copenhagen: 2011.

Roy 2010 . Roy YM, Derry S, Moore RA. Single dose oral lumiracoxib for postoperative pain in adults. Cochrane Database of Systematic Reviews. 2010; (7) DOI: 10.1002/14651858.CD006865.pub2.

Ruff 2011 . Ruff CT, Morrow DA, Jarolim P, Ren F, Contant CF, Kaur A, et al. Evaluation of NTproBNP and high sensitivityC-reactive protein for predicting cardiovascular risk in patients with arthritis taking longterm nonsteroidal antiinflammatory drugs. Journal of Rheumatology. 2011; 38(6):1071-8. DOI: 10.3899/jrheum.100880. [PubMed: 21459935]

Straube 2005 . Straube S, Derry S, McQuay HJ, Moore RA. Effect of preoperative Cox-II-selective NSAIDs (coxibs) on postoperative outcomes: a systematic review of randomized studies. Acta Anaesthesiologica Scandinavica. 2005; 49(5):601-13. [PubMed: 15836672]

Toms 2008 . Toms L, McQuay HJ, Derry S, Moore RA. Single dose oral paracetamol (acetaminophen) for postoperative pain in adults. Cochrane Database of Systematic Reviews. 2008; (4) DOI: 10.1002/14651858.CD004602.

Tramèr 1997 . Tramèr MR, Reynolds DJ, Moore RA, McQuay HJ. Impact of covert publication on meta-analysis: a case study. BMJ (Clinical research Ed.). 1997; 315(7109):635-40.

* Indicates the major publication for the study 


\section{PLAIN LANGUAGE SUMMARY}

\section{Single-dose oral celecoxib for postoperative pain}

Celecoxib was one of the first of the new generation of non-steroidal anti-inflammatory drugs (NSAIDs) known as COX-2 inhibitors. Compared with conventional NSAIDs celecoxib has fewer gastrointestinal side effects with long-term use. It is used for the relief of chronic pain caused by osteoarthritis and rheumatoid arthritis. This review examined the efficacy of celecoxib in relieving acute pain. Eight trials provided data. Just over 3 in 10 people (33\%) taking celecoxib $200 \mathrm{mg}$, and over 4 in 10 (44\%) taking celecoxib $400 \mathrm{mg}$ experienced a good level of pain relief (at least 50\%), compared with about 1 in 10 (range 1 to $11 \%$ ) with placebo. Indirect comparisons indicate that the 200 $\mathrm{mg}$ dose of celecoxib is at least as effective as aspirin 600/650 $\mathrm{mg}$ and paracetamol (acetaminophen) $1000 \mathrm{mg}$ for relieving postoperative pain, while a $400 \mathrm{mg}$ dose is at least as effective as ibuprofen $400 \mathrm{mg}$. Adverse events occurred at a similar rate with celecoxib and placebo. One serious adverse event (rhabdomyolysis - muscle breakdown) was probably related to celecoxib. Withdrawals due to adverse events were few and occurred at similar rates with celecoxib and placebo. 


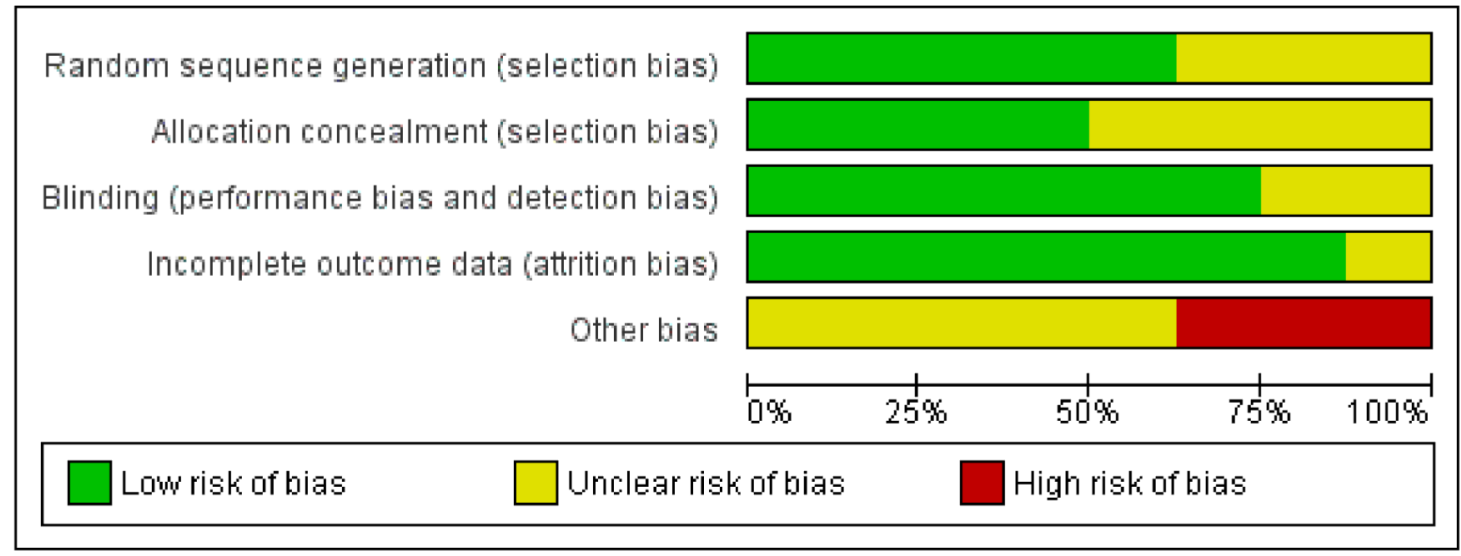

Figure 1. 'Risk of bias' graph: review authors' judgements about each risk of bias item presented as percentages across all included studies 


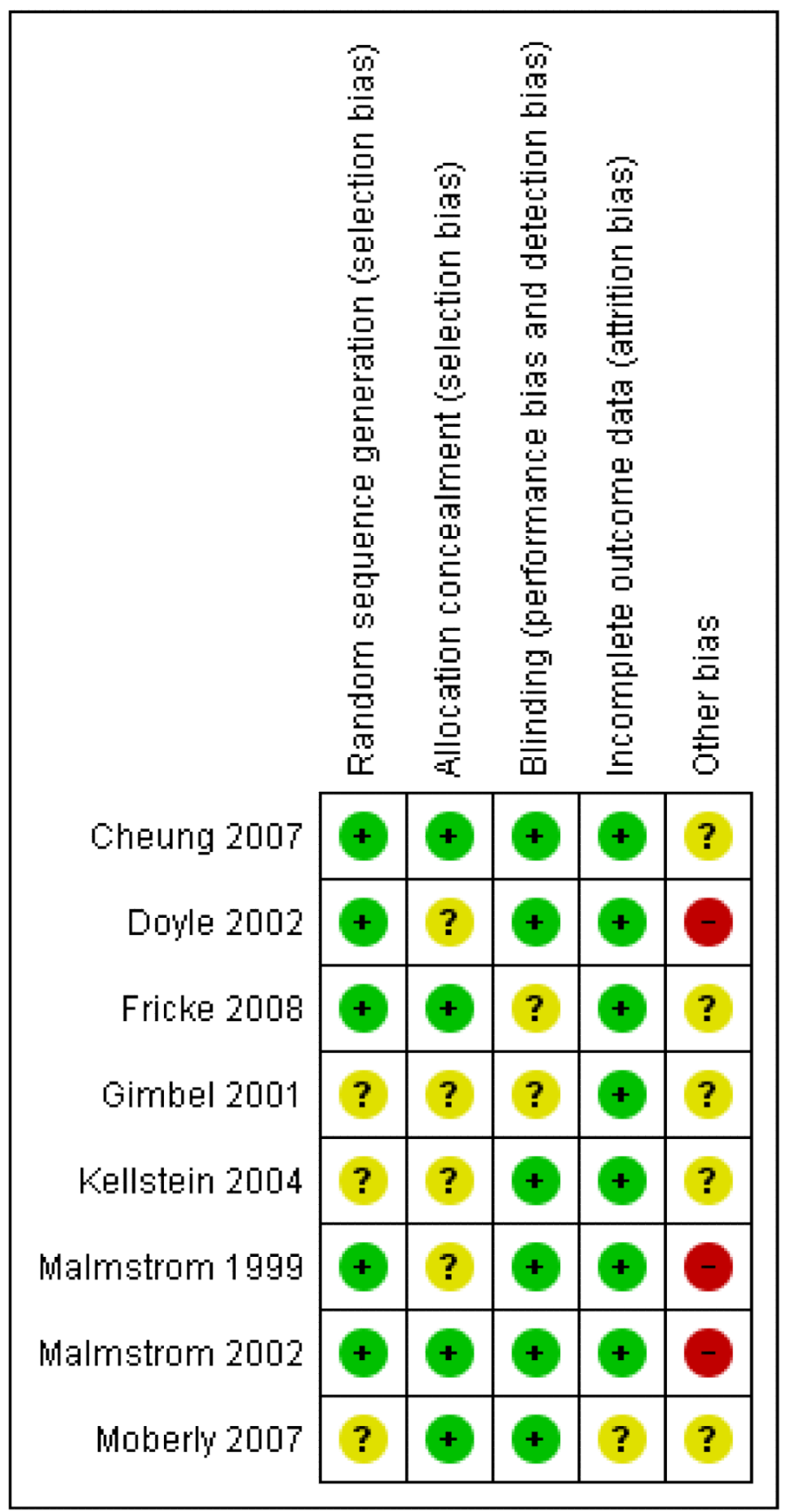

Figure 2. 'Risk of bias' summary: review authors' judgements about each risk of bias item for each included study 


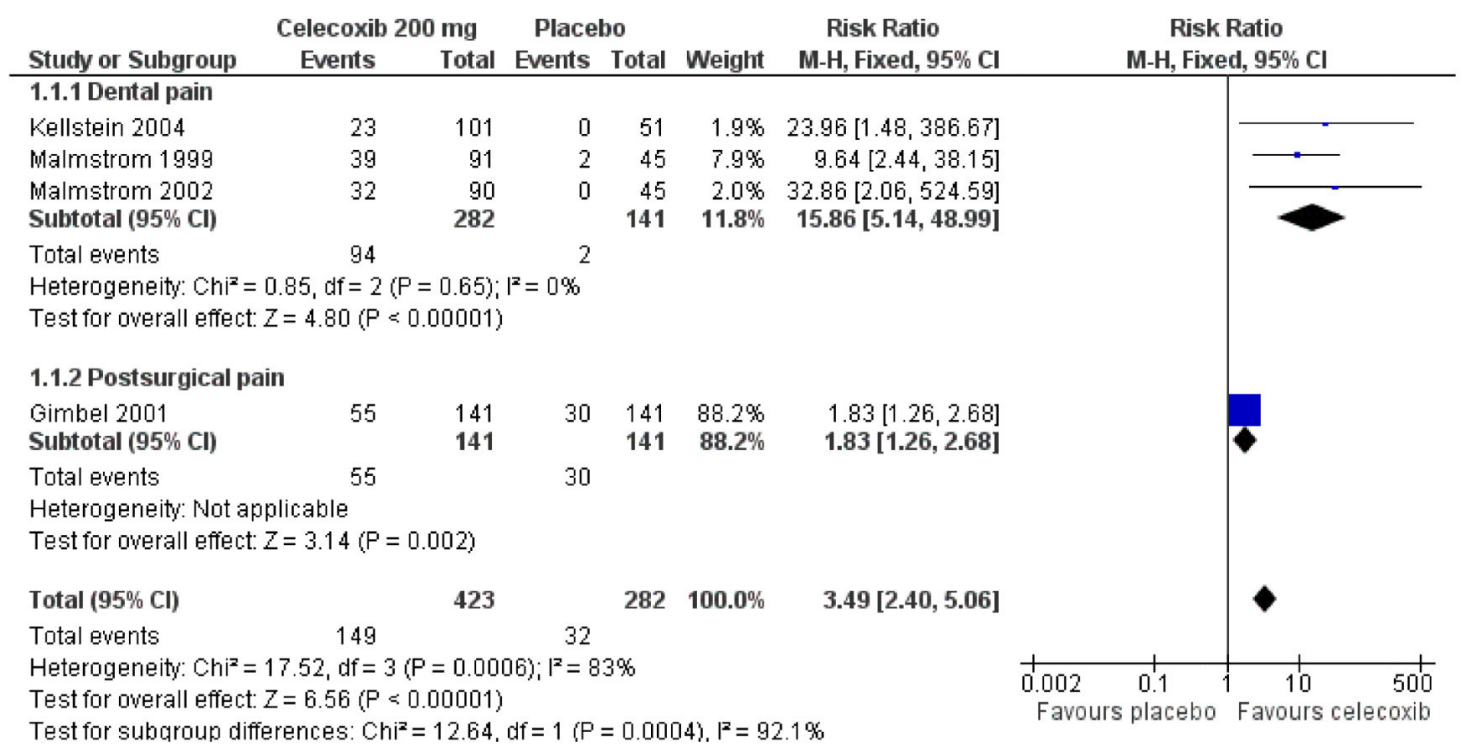

Figure 3. Forest plot of comparison: 1 Celecoxib $200 \mathrm{mg}$ versus placebo, outcome: 1.1 At least $50 \%$ pain relief over 4-6 hours 


\begin{tabular}{|c|c|c|c|c|c|c|c|c|c|}
\hline \multirow[b]{2}{*}{ Study or Subgroup } & \multicolumn{2}{|c|}{ Celecoxib 400 mg } & \multicolumn{2}{|c|}{ Placebo } & \multirow[b]{2}{*}{ Weight } & \multirow{2}{*}{$\begin{array}{l}\text { Risk Ratio } \\
\text { M-H, Fixed, 95\% Cl }\end{array}$} & \multirow{2}{*}{\multicolumn{3}{|c|}{$\begin{array}{c}\text { Risk Ratio } \\
\text { M-H, Fixed, 95\% Cl }\end{array}$}} \\
\hline & Events & Total & Events & Total & & & & & \\
\hline Cheung 2007 & 36 & 57 & 5 & 57 & $47.5 \%$ & $7.20[3.05,17.02]$ & & & $-\square$ \\
\hline Fricke 2008 & 49 & 156 & 0 & 52 & $7.1 \%$ & $33.42[2.10,532.45]$ & & & \\
\hline Malmstrom 2002 & 74 & 151 & 0 & 45 & $7.3 \%$ & $45.09[2.85,713.49]$ & & & \\
\hline Moberly 2007 & 25 & 51 & 4 & 51 & $38.0 \%$ & $6.25[2.34,16.68]$ & & & $=-$ \\
\hline Total $(95 \% \mathrm{Cl})$ & & 415 & & 205 & $100.0 \%$ & $11.47[5.85,22.49]$ & & & \\
\hline Total events & 184 & & 9 & & & & & & \\
\hline $\begin{array}{l}\text { Heterogeneity: } \mathrm{Chi}^{2}= \\
\text { Test for owerall effect }\end{array}$ & $\begin{array}{l}4.11, d f=3 \\
Z=7.10(\mathrm{P}\end{array}$ & $\begin{array}{l}0.25) ; \\
00001)\end{array}$ & $P=27 \%$ & & & & $\begin{array}{l}0.002 \\
\text { Favoul }\end{array}$ & $\begin{array}{c}0.1 \\
\text { placebo }\end{array}$ & $\begin{array}{cc}10 & 500 \\
\text { Favours celecoxib }\end{array}$ \\
\hline
\end{tabular}

Figure 4. Forest plot of comparison: 2 Celecoxib $400 \mathrm{mg}$ versus placebo, outcome: 2.1 At least $50 \%$ pain relief over 4-6 hours dental pain 